\title{
A VINGANÇA DO BAIXO CLERO: O DESAFIO AO "PIG" E O ESTADO DO CONFLITO CULTURAL NO TRATAMENTO DA CRISE FINANCEIRA
}

Roberto Grün

\section{Introdução}

Em 1986 foi publicado o livro A universidade em ritmo de barbárie (Giannotti 1986) e da sua repercussão começou a ser popularizado o termo "baixo clero" como categoria nativa utilizada nos embates na esfera acadêmica e posteriormente em outras, como na política e na própria Igreja. No seu senso estrito, o termo se refere ao estrato subordinado dos religiosos na hierarquia católica da França do Ancien Régime (Gangneux 1959). O uso da expressão ou correlatos na sua acepção intelectual mais ampla tem uma linhagem já longa, remontando pelo menos a Burke e Voltaire (Chartier 1982). A maneira como foi apropriada, tratada e flexionada no Brasil recente acabou "encantando" os problemas sociológicos nos quais ela se inscreve. Mas esse encantamento tornou ainda mais fascinante os efeitos cruzados da nominação e da reação a ela. ${ }^{1}$

Sugiro neste texto que a partir dessa discussão podemos encontrar pistas para uma boa explicação da lógica social e das circunstâncias em que os governos federais petistas tiveram algum sucesso, apesar da crítica cerrada dos órgãos de comunicação e de boa parte das elites culturais do país. Esses governos foram formados em grande parte por indivíduos que poderiam ser catalogados como do baixo clero intelectual e político, e o sucesso pode ser medido objetivamente pela reeleição de Lula e mais ainda pela eleição de Dilma em 2010. Para aqueles que o apoiam, podemos enumerar entre suas consequências o fato de ter alterado dados que pareciam "naturais" da sociedade brasileira, como a impossibilidade de políticas redistributivas diretas eficientes e diversas formas de inclusão social e de aumento do nível de bem-estar dos grupos subalternos através de políticas estatais ativas. E, principalmente, o Estado brasileiro se tornou maior e passou a ser considerado mais eficiente num quadro dóxico internacional totalmente avesso a esse tipo de inflexão, que faz 
enxergar como óbvia, justa e correta a tendência exatamente oposta àquela que por aqui observamos (IPEA 10/2011). A partir da crise financeira deflagrada em 2008, a oposição à tendência internacional ficou ainda mais aguda e evidente e podemos então dizer que aconteceu uma mudança importante e contraintuitiva que merece um esforço sociológico para lhe dar inteligibilidade.

Uma boa pista fenomenológica, que se torna operacional para começar a explicar esse sucesso, está no desfazimento de um traço essencial da ação ideológica dita "neoliberal", que é a separação absoluta entre realidade econômica e realidade social. O predomínio da razão financeira que se extrai do chamado "fundamentalismo de mercado" tem neste princípio uma das suas principais âncoras, que deflagra as sequências automáticas de significado que produzem o bom senso imperante no espaço em que ela domina. Interromper essa cadeia mnemônica que, como mostra a crise financeira internacional, é uma das associações cognitivas mais fortes da contemporaneidade, é um feito que demonstra uma enorme vitalidade no eixo da imposição e da rejeição de arbitrários culturais.

A cadeia mnemônica que forma a coluna vertebral da doxa dominante se ampara na extrapolação da lógica da economia individual ou doméstica para aquela que deve gerir a conduta econômica da nação. Em especial durante as crises, as famílias devem "apertar os cintos", restringindo gastos, adiando investimentos e tentando encontrar novas fontes de renda; da mesma maneira, os países deveriam enfrentar as crises tendo como padrão de conduta o mais rigoroso controle orçamentário (Lakoff 1996; Douglas 1998). Os embates políticos que acompanhamos nos Estados Unidos e na União Europeia nesse início de segunda década do século XXI mostram como essa ideia se transformou em doxa, como obviedade indiscutível, sua robustez e a dificuldade de se ir contra ela.

No contexto acima, sustentar e implementar a ideia dita "keynesiana", segundo a qual o aumento de gastos públicos e também do consumo privado são respostas adequadas para a crise, é um feito que merece destaque. Entretanto, o governo petista "do baixo clero" foi capaz de lançar uma política contraintuitiva e, muito mais importante para essa análise, defendê-la na arena pública e referendá-la através da eleição da presidenta Dilma mesmo no meio da crise. E, posteriormente, durante seu governo, ampliar o quadro de heresias sem que, até meados de 2012, a ortodoxia tivesse conseguido organizar um auto de fé em pompa e circunstância para condenar os hereges, purgar esses pecados, punir os pecadores, mostrar aos céus a devoção dos verdadeiros crentes e assim restaurar a boa ordem cósmica. Independente da justeza estritamente econômica da novidade na conduta macroeconômica, ela é uma verdadeira "prova do pudim" que revela a vitalidade do novo gru- 
po no eixo cultural. Isto dito, ela traz perguntas obrigatórias sobre a efetiva distribuição de capital cultural na sociedade brasileira contemporânea.

\section{O baixo clero em tempos normais e em outros}

Em condições normais de temperatura e pressão, o baixo clero simplesmente acata as diretrizes intelectuais e institucionais do "alto clero", das elites culturais ou políticas bem reconhecidas nas respectivas sociedades. Os membros do baixo clero tentam a todo custo se diferenciar uns dos outros, visando obter individualmente o reconhecimento do alto clero, sendo o principal resultado dessa competição a reiteração e a naturalização da hierarquia cultural e política da sociedade. As coisas funcionam normalmente e não há problema nenhum. A presença do nosso baixo clero é notada justamente quando a natureza começa a mostrar sinais de revolta e a hierarquia, através das formas tradicionais de reconhecimento e submissão, deixa de impor seu ordenamento classificatório nos produtos e nas ações culturais e políticas.

Nas tentativas do baixo clero de subverter a hierarquia em seu favor, ele é considerado uma "força incontrolável da natureza" que pode produzir diversos tipos de pressão e desaguar seus resultados em distintas áreas e direções, tanto as consideradas progressistas quanto aquelas tidas como conservadoras ou reacionárias. O que unificaria as diversas manifestações da quebra da hierarquia promovida pelo baixo clero seria a forma dessas intervenções. Elas seriam sempre "plebeias", grosseiras e de mau gosto. Em suma, espúrias em relação àquilo que o respectivo espaço, vocalizado pelo seu patriciado, considera como legítimo, belo e virtuoso. Um exemplo visto como extremamente "negativo" foi o dos intelectuais identificados com o nazismo que exploraram o espírito "Völkisch", o populismo cultural alemão e austríaco, indo contra e mesmo eclipsando a alta cultura germânica, tida como um dos pontos fortes do universalismo cultural da época. A exploração mais interessante talvez seja a análise em torno da trajetória ${ }^{2}$ e do papel de Goebbels, que inicia sua vida intelectual como pequeno literato tentativo, progressista e ligado ao expressionismo e que, em poucos anos, se torna o principal ideólogo do movimento nazista e personalidade mais próxima de Hitler, ele mesmo pintor de pouco sucesso (Mosse 1998; Timms 2005).

Do outro lado do tabuleiro moral e muito mais explorado pela história cultural, encontramos aqueles intelectuais que identificamos como os principais da Revolução Francesa, os quais, inicialmente também pequenos cidadãos da república das letras, irão ser os mais destacados tribunos e dirigentes dos 
primeiros governos revolucionários. Antes da revolução, não passavam de "pobres diabos", ou "escrevinhadores" de pouco talento e muita pretensão, que se dedicavam normalmente a difamar os grandes de sua época e a inventar conspirações crapulosas e fantasiosas que poderiam despertar o interesse do público simplório para o produto de suas atividades e, indiretamente, contribuir para a dessacralização do Ancien Régime. Na revolução acabaram assumindo postos e responsabilidades que iam muito além de suas capacidades e os excessos do período poderiam ser debitados a essa disjunção (Darnton 1983; Chartier 2000; Darnton 2010; Pelleport \& Darnton 2010).

De ambos os extremos assistimos à quebra do status quo, mas com consequências evidentemente opostas. E não precisamos de muito tirocínio político para imaginar os jogos de atribuição que serão deflagrados a partir das interpretações da História. Em momentos de contestação, o baixo clero desafiante irá procurar a familiaridade do momento com as circunstâncias de eventos como a Revolução Francesa, exaltando a necessidade da transgressão para fazer emergir o progresso social, científico ou político. Do seu lado, os defensores da ordem tradicional tentarão construir paralelismos que aproximem as circunstâncias e os indivíduos de destaque do momento àqueles episódios trágicos de consequências universalmente consideradas funestas, como o da eclosão do nazismo e a barbárie que aquele movimento deflagrou.

Analiticamente, o baixo clero - ou o proletariado intelectual ou, como querem (Weber 1995) os intelectuais, "proletaroides" (:267-270, $2^{\circ}$ vol.) — é uma espécie de efeito indesejado, mas incontornável dos sistemas de ensino nacionais. Os sistemas têm de ser seletivos e nem todos que por ele passam podem receber os bons diplomas, muito menos aceder aos bons postos. É assim uma tendência estrutural que boa parte dos estudantes não consiga trilhar até o final os caminhos que os levariam às elites intelectuais (Faguer 1995). O problema é o que fazer com esses aspirantes excluídos e desiludidos, em especial quando eles conseguem construir algum sistema de equivalências que pode dizê-los formalmente iguais aos "verdadeiros" intelectuais (ou políticos) e, portanto, merecedores das mesmas recompensas materiais e simbólicas. Nesse momento surge o anátema que tenta reconduzir o espaço intelectual (ou religioso, ou político, ou profissional) ao caminho e ao funcionamento corretos. Nele, os grandes pontificam/produzem as verdades, e os pequenos simplesmente as difundem, sendo tolerada apenas a simplificação dos argumentos e dos procedimentos para serem entendidos e aplicados pelo grande público, seguindo o exemplo original que vai da teologia culta até o sermão a ser proferido entre os simplórios da paróquia rural. Qualquer contestação a essa ordem natural é a... barbárie. 


\section{A morfologia do problema}

Períodos de expansão ou alterações nas lógicas de reprodução dos sistemas de ensino superior ou de acesso aos cargos de representação política são os momentos mais favoráveis para a eclosão do "problema" do baixo clero. Títulos de nobreza intelectual e política que antes eram mais raros se generalizam, e os seus titulares, que em épocas anteriores não teriam acesso às formações e às posições respectivas, cobram da sociedade os proveitos que anteriormente ela concedia aos privilegiados. Em especial no universo cultural, raramente essas posições existem, já que a sincronia entre os sistemas de ensino e o resto da sociedade é muito pouco provável. E no sistema político assistimos à eterna lamúria da falta de homens políticos dotados da visão e da retidão que, se imagina, tiveram os de outrora.

Para o nosso baixo clero sobra então a possibilidade de desalojar aqueles que já ocupam as posições cobiçadas, e aí o jogo pega fogo. Há duas maneiras de se tentar desalojar os ocupantes tradicionais. A mais óbvia é fazer passar que o grupo mais novo é melhor no jogo previamente estabelecido. A outra é tentar mudar as regras do jogo. $\mathrm{Na}$ primeira hipótese, quando falamos do espaço intelectual, as chances do grupo desafiante são definitivamente pequenas, já que os ocupantes tradicionais e os herdeiros por eles legitimados têm mais bem incorporadas as regras e a lógica do jogo jogado até o momento em questão e por isso são estruturalmente mais bem preparados para ele. A segunda hipótese parece mais promissora para os desafiantes. Mas ela carrega a dificuldade estrutural de como fazer a sociedade aceitar que o jogo precisa mudar. E antes dela, diminuir as dúvidas dos próprios desafiantes, que também foram formados nos cânones tradicionais e normalmente estão absorvidos pela competição horizontal interna visando ao seu reconhecimento individual pelo alto clero.

Mesmo nas poucas situações em que eles mesmos estão convictos de que as mudanças devem ocorrer e eles são seus principais agentes, é muito difícil desfazer a impressão de que os desafiantes são menos legítimos. Logo suas pretensões são facilmente ridicularizáveis nos diversos tribunais da opinião pública, dentre os quais ocupam os lugares principais as agências de fomento estatal que financiam as atividades culturais e a imprensa que as consagra, bem como as eventuais novidades políticas. Evidentemente a inércia que favorece os já estabelecidos depende da chance, em geral muito grande, de que os ocupantes dos cargos de decisão naqueles "tribunais" tenham sido formados pela ordem cultural e política tradicional e a acatem. Nesse contexto, o controle dos tribunais da opinião pública se torna uma questão de vida e morte que pode dar sobrevida aos primeiros. Opostamen- 
te, pode apressar ou viabilizar as carreiras dos últimos. Bem se vê que as situações em que alguns grupos tentam inscrever a pecha de "ridículos" nos seus adversários são bem mais do que ocasiões e peculiaridades hilariantes. São expressões do uso das armas fundamentais no conflito simbólico, que visam deslegitimar as pretensões dos grupos emergentes ou as razões do predomínio das elites tradicionais (Farge 1992; Chartier 2000).

Para sustentar a análise, poderíamos apresentar estatísticas do número de egressos do ensino superior e, mais precisamente, das suas formações doutorais que culminam na consagração oferecida pelo sistema. Mas esses indicadores apenas apresentam a possibilidade de eclosão do nosso problema. Ele se configura efetivamente quando examinamos contenciosos culturais (que ao mesmo tempo são políticos e econômicos) nos quais a barbárie e o baixo clero, diretamente ou de maneira disfarçada, são invocados como responsáveis pelas perturbações da ordem. E o Brasil contemporâneo, no qual os universos das elites em geral, da cultura e da política estão em expansão continuada, é um verdadeiro viveiro dessa espécie e de seus derivados (Grün 2005).

Uma questão evidente é a da aplicação das cotas raciais e sociais para o ingresso no sistema público de ensino superior. As universidades mais antigas e tradicionais, que concentram a reprodução legítima das elites intelectuais, foram obrigadas a correr atrás de uma agenda que era típica do "baixo clero" e responder a perguntas que não foram formuladas por elas. O sistema meritocrático integral, que reservava os lugares cobiçados dos cursos de graduação aos melhores alunos medidos pela escala dos exames vestibulares, foi sendo progressivamente questionado até a consagração da prática das cotas na sentença unânime do STF validando o sistema de ação afirmativa (STF 26/04/2012).

Um ponto menos evidenciado é que essa conspurcação e um aumento vertiginoso do sistema universitário federal e, reativamente, também dos sistemas estaduais, em especial no estado de São Paulo, ocorreram lado a lado. Abriram-se enormes espaços para a formação de qualidade considerada boa para uma quantidade muito maior de jovens, e também vagas de professores nominalmente do mesmo nível dos ocupantes tradicionais dos cargos. Vemos assim uma versão brasileira contemporânea dos dois lados do problema: a ampliação do contingente que pode, nominalmente, reivindicar a condição de intelectual e a imposição de uma problemática externa àquelas consideradas relevantes e pertinentes, "criando um problema que antes não existia". No caso, "racializando" as relações sociais no Brasil onde antes, segundo o cânone desafiado, esta questão era derivada de outras, exteriorizada e solucionável a partir da flexão de variáveis que não ameaçariam a 
ordem cósmica, como a melhoria dos ensinos públicos de primeiro e segundo graus. Dessa forma, registrando seu aspecto implicitamente espúrio, que a inscreve no padrão internacional de subversões da ordem intelectual (e cósmica) típicas do baixo clero.

\section{O "mensalão" e o ardil da razão social}

Mas o tópico da subversão do status quo intelectual e político fica muito mais explícito quando o tema só aparece de maneira indireta, camuflada e justamente em algumas questões que alteram substancialmente a paisagem política e econômica do país. Penso na sequência de eventos que começou com o escândalo do mensalão e prosseguiu na eleição presidencial de 2006. Primeiramente, a ideia de que "pobre quando come melado se lambuza", presente nas denúncias das práticas políticas do PT no Congresso e no governo denunciadas durante o escândalo e depois na "central de boatos petista" que teria se constituído para conseguir a reeleição de Lula. E, pari passu, a transformação dos dizíveis e factíveis na condução estatal da economia brasileira e da própria estrutura organizacional do Estado (Grün 2008a).

Nos primeiros anos do primeiro governo Lula, a ordem cósmica parecia ter se recobrado da anomalia na mecânica celeste. O predomínio dóxico tinha sido um pouco arranhado pelo "apagão elétrico" dos últimos anos de Cardoso, mas a memória desse embaraço tendia a se apagar. ${ }^{3}$

Apesar da eleição de Lula, a condução da economia era enxergada como uma cópia daquela empreendida pelos membros da equipe do real, os quais, como veremos adiante, reuniam os principais atributos para serem considerados membros do "alto clero". A discussão era se a "lição de casa" realizada pela primeira equipe de Lula estava, ou não, sendo bem feita. Independente da "real" condução da economia, tudo indicava que nosso baixo clero, mesmo ousando ocupar cargos além de sua competência, acabava, em última instância, respeitando a hierarquia "natural". Os possíveis argumentos em favor da originalidade da política econômica do primeiro Lula eram relevados e, tipicamente para nossos propósitos, sequer discutidos pelos tribunais da opinião.

Há, evidentemente, uma ambiguidade estruturante nessa noção de opinião. Longe das eleições ou de algum raro fenômeno de intensa participação popular, a opinião pública se confunde com a opinião publicada e só têm acesso à publicação os atores sociais já legitimados pelas escalas de prestígio preexistentes. Nem é preciso dizer que tal situação favorece a doxa. E assim, fora de momentos extraordinários da história, a opinião pública 
começa a se aproximar da opinião popular apenas quando as eleições se aproximam e as pessoas "comuns" começam, elas mesmas, a se interessar pelos temas morais, econômicos e políticos que podem dividir a nação, também não coincidindo com a opinião majoritária das elites tradicionais (Gaxie 1978; Champagne 1990).

Naquele primeiro momento de Lula, no qual a opinião pública/publicada desconfiava das qualidades do seu grupo e, muito provavelmente, também ele e seu grupo partilhavam dessa opinião, dificilmente poderíamos encontrar uma expressão melhor do que a "lição de casa" para servir de escala para a qualidade da gestão estatal, em especial a da economia. Um bom marcador para esse contexto foi o transcorrer e o desfecho da primeira grande iniciativa parlamentar do governo, a regulamentação do artigo sobre o sistema financeiro nacional através da PEC 192. ${ }^{4}$ A pretensão inicial, tida como heterodoxa, foi ridicularizada pela opinião publicada, sem que algum apoio público relevante pudesse contrabalançar a caracterização. Em seguida, o próprio governo recuou de suas intenções, até ter sido aprovada uma versão consideravelmente mitigada, não sem antes se desfazer de sua incômoda ala esquerda, que criticava o que considerava ser a tibieza de Lula e seus próximos.

Mas mais do que o resultado propriamente dito, o essencial do episódio para meu propósito atual foi que ele revelou a relação cultural de forças que era contrária ao novo governo e que passava por cima da legitimidade política obtida nas urnas das eleições presidenciais de 2002. O baixo clero, mesmo investido de poder político formal, deveria ser "responsável", se restringir a ser um zeloso aplicador da ortodoxia dominante, sem ousar fazer nada além do "razoável". Deveria mesmo, como várias vezes foi insinuado, se mostrar aluno exemplar e ser ainda mais zeloso do que seus mestres na aplicação da ortodoxia. O que era permitido e mesmo incentivado era uma "lição de casa" tão bem feita a ponto de ser reconhecida como um avanço na racionalidade econômica pretendida pelos tenores da ortodoxia.

\section{O "PiG" e a inversão da ordem natural das coisas}

O terremoto político dos eventos em torno do "mensalão" alterou não só a ordem política como também a ordem cósmica. Há diversas entradas possíveis que dariam sentido ao período ou ao episódio. Aqui interessa mais um aspecto da disputa política daquele momento, que foi a ideia da existência de uma conspiração das elites tradicionais contra o governo petista, operacionalizada pelos políticos da oposição, membros do Poder Judiciário, da 
polícia federal e polícias estaduais e principalmente pela chamada "grande imprensa". Numa primeira leitura, decalcada diretamente da literatura acadêmica sobre o tema, seria altamente esperado que nosso "baixo clero" inventasse explicações conspiratórias para fazer entender o que o alto clero passou a considerar como seus deslizes e fracassos. E, efetivamente, assistimos a essa ocorrência. Especialmente criando entidades consideradas mais ou menos fantasmagóricas e fantasiosas pelas elites tradicionais, como a chamada "grande imprensa", cognominada na época de "PiG". ${ }^{5}$ Mas o que vem depois e na sua cauda é o mais interessante e ajuda a explicar a originalidade da situação brasileira contemporânea.

Intelectuais individuais e grupos criam cotidianamente novas caracterizações que podem, ou normalmente não, servir de base - em geral por analogia e uso metafórico - para explicar os fenômenos com os quais a sociedade se defronta. Numa versão mais radical, essas novidades acabam efetivamente constituindo a realidade por oferecerem um caminho que cria determinada consistência e relação entre os fatos e, correlativamente, desfaz a possibilidade de os eventos adquirirem outra inteligibilidade (McCormick 1996). O investimento da energia política e econômica da sociedade em objetivos estabelecidos a partir da correlação apontada acaba por construir a própria realidade, antes apenas esboçada. Uma possibilidade dentre diversas alternativas foi escolhida e será a partir dela que a sociedade será pensada daquele momento em diante (Hacking 1983; Bourdieu 1997; Douglas 1998).

A própria caracterização do "baixo clero" como categoria pertinente para o debate intelectual que depois migra para o debate público é um bom exemplo de conceito estruturante. Mas também é um mau exemplo... Por ser uma produção do "alto clero", goza de naturalidade e não é percebida como a imposição ao mesmo tempo de um arbitrário cultural e de uma agenda a ser discutida pela sociedade. Já o nosso "PiG", que vem de grupos menos legitimados e que também acaba se tornando uma categoria forte para estruturar a realidade, este carrega um estigma que torna o seu uso menos "natural". A sua aceitação pelos membros dos grupos tradicionais é oblíqua e eivada de tentativas de ridicularização, mas se torna um fato, como mostram colunas de opinião dos meios de comunicação mais consagrados (Neto 02/12/2011; (ombudsman) 18/12/2011; Guzzo 22/07/2009). Entretanto, ele também entrou no léxico e temos de admitir que quem o fez nascer também possui essa força sobre a sociedade que a faz utilizar o conceito para entender a realidade contemporânea. Na linguagem de Bourdieu, é impossível deixar de reconhecer o capital cultural e simbólico dos blogueiros que o jogaram na corrente do linguajar brasileiro, que tenta dar conta dos embates culturais que estão sendo travados durante os governos petistas, 
tendo por objeto a qualidade de seus atos e atores. Ou, na linguagem do materialismo cultural aplicado à sociologia, poderíamos falar na retenção do termo e implicitamente do argumento, o que indicaria a sua institucionalização (Schudson 1989).

A análise da dinâmica da criação da entidade PiG também é altamente indiciária para nossa problemática. Ela é uma chave que pode esclarecer a dinâmica cultural que deu consistência aos governos petistas e assegurou que o desafio à ordem cósmica não tenha tido como consequência a imolação dos transgressores, apesar das diversas tentativas de se produzir o auto de fé purificador. Diante dessas tentativas, assistimos a uma construção concorrente da realidade que esvaziou a pressão da cultura política tradicional ultrajada. E também indicou, indiretamente, que os ultrajados estavam sendo ultrapassados. Afinal, o exorcismo da ridicularização não foi suficiente para retirar a nova entidade do espaço cognitivo. Logo, nossos exorcistas tradicionais começavam a perder o fundo de comércio que os sustentava simbólica e economicamente. Não eram somente opiniões que estavam sendo desafiadas, eram identidades e o prestígio intelectual que garante autoestima, comendas e encomendas. Não é assim por acaso que assistimos a uma intensificação inédita da guerra cultural, trocas de acusações violentíssimas e o uso indiscriminado de um linguajar normalmente considerado chulo, que foi se naturalizando no decorrer dos enfrentamentos e que frequenta contemporaneamente nossa internet, como antigamente passeava nos libelos e nos panfletos que caracterizavam os subterrâneos literários da imprensa recém-nascida. ${ }^{6}$

Usando a linguagem de Bourdieu (1977), assistimos à perda do monopólio da violência simbólica legítima por parte do nosso alto clero. E se quisermos ir mais longe, podemos acompanhar o mesmo autor em conjunto com o filósofo Bouveresse analisando as contribuições seminais de Karl Kraus para as guerras culturais, em especial aquelas travadas ou veiculadas através da mídia contemporânea, em gestação nos tempos dele. Evidencia-se nessas digressões o papel central da grande imprensa por causa do "monopólio da difamação legítima" de que ela dispõe nas sociedades contemporâneas (Bourdieu \& Bouveresse 2000; Bouveresse 2001) E, em paráfrase, poderíamos dizer que o período que analisamos mostrou um processo de "perda do monopólio da difamação legítima" no contexto brasileiro do início do século XXI. E um pouco mais além, as formulações francesa e inglesa a partir de situações das realidades desses países também nos indicam que o problema aparentemente apenas brasileiro e pretensamente revelador da imaturidade da sua sociedade civil é relevante para diversos países considerados do I Mundo da contemporaneidade (Coletivo 2006; Boltanski 2012). 


\section{Conspiração: "fato" e estratégia}

Indo muito além de uma relação simples entre baixo clero e teoria da conspiração, indicando a pouca arte de quem formula semelhantes "confabulações" e ainda a menor argúcia de quem nelas acredita, assistimos no período a vários exemplos de usos estratégicos das ideias sobre conspiração. No auge da crise do mensalão apareceu a "versão Daniel Dantas", que imputava ao financista a deflagração do escândalo por ter seus interesses contrariados nas disputas com os fundos de pensão a propósito do controle das empresas de telecomunicações recentemente privatizadas. Nessa narrativa, Dantas teria não só municiado Roberto Jefferson com as informações, como também o teria recompensado com uma enorme soma de dólares. Em seguida, apareceu a segunda versão da conspiração, na qual as elites como um todo estariam tentando desestabilizar o governo petista, desgostosas com os seus rumos e com a mácula estética de o país ser liderado por um torneiro mecânico (Grün 2008a).

Aqui, antes de aceitar ou negar as versões, creio ser uma boa estratégia epistemológica lembrar que a possível comprovação delas está muito além da falsificabilidade popperiana. E, muito mais importante do que isso, é fundamental prestar atenção nos seus efeitos sobre uma realidade que elas, de maneira marota, parecem apenas descrever. Na verdade, é necessário ter presente que essas versões são instrumentos para interferir e conformar a própria realidade de acordo com as estratégias dos grupos que as divulgam ou as tentam ridicularizar (Bourdieu 1981). E de fato, da conspiração, com ou sem aspas, com ou sem credibilidade na grande imprensa ou na alta cultura, surgiu a estratégia da divulgação dos pontos de vista do governo e do principal partido que lhe dá sustentação através dos usos sociais da nova mídia que passamos a chamar de "blogosfera" e a compactação de um bloco de defensores dessa política e desse governo. E mesmo diante da ofensiva simbólica perpetrada pelo "PiG", a tropa petista não se dispersou diante da crítica que a ridicularizava e efetivamente se preparou para a batalha ao mesmo tempo política e simbólica que se seguiu, além de cobrar de seus chefes, agora em posição de força, as promessas da campanha e da lógica da família política de que faziam parte (Grün 2008b) .

Um aspecto interessante é ver que o feitiço virou contra o feiticeiro. O escândalo configurado como uma "missa", organizada para purificar o país da conspurcação que foi a condução política legislativa conduzida pelo baixo clero, o malfadado "mensalão", gerou não exatamente a purificação de costumes desejada de forma explícita, mas de fato uma espécie de "contramissa" dos apoiadores do governo baseada justamente na necessidade de se 
contrapor à conspiração das elites (Grün 2008b; Collins 2004) — dois bons exemplos de celebração de vínculo societário que estrutura a sociologia da religião de corte durkheimiano. Em ambos a existência "real" da divindade invocada tem importância bem menor do que os processos de mobilização que foram deflagrados, fazendo com que os apoiadores de cada lado cerrassem fileiras, dando consistência aos dois campos e preparando-os para a luta ao mesmo tempo cultural e política a que estamos assistindo em torno da definição do Brasil contemporâneo. ${ }^{7}$

A ação reativa foi conformada principalmente no que passou a ser chamado, naquele momento, de "blogosfera", o novo espaço público de expressão propiciado pela internet e, em especial, pelas chamadas redes sociais que nela se abrigam e expressam. Muito provavelmente a reação não convenceu o "alto clero" de que o novo grupo no poder estava encaminhando o país para um bom futuro. Mas produziu uma interrupção decisiva nos canais de difusão cultural que costumam fazer com que a ortodoxia intelectual vire doxa social, e diminuiu as chances e a força da censura tradicional ${ }^{8}$ (Grün 2008b). Esse caminho, cuja ação nas sociedades contemporâneas começa a se esclarecer, faz normalmente com que as produções das elites culturais, em particular os economistas conservadores que enunciam o bom caminho para as políticas de governo identificadas com o "neoliberalismo", ecoem, sendo trabalhadas e difundidas por todo o espectro social através dos comunicadores populares - jornalistas, locutores, radialistas, líderes religiosos e outros. E essa capilarização se intensifica até que a ortodoxia, transformada em sabedoria popular também conservadora pelos comunicadores populares, seja considerada tanto como o conjunto dos objetivos pertinentes como o dos limites óbvios das ações governamentais (Jamieson \& Cappella 2008).

Uma boa operacionalização do tópico foram as tentativas de desqualificar o programa "bolsa-família", que seguiram o roteiro que normalmente dá certo, ridicularizando as ações heterodoxas até que seus próprios impulsionadores desistam. Diante da inegável aceitação social, medida mais uma vez de maneira indireta pelas eleições gerais em que os petistas foram vitoriosos, a capilarização foi interrompida e o futuro dirá se ela efetivamente se tornou um direito inequívoco da cidadania. O próprio embate político pode acabar ajudando nessa institucionalização. Seguindo nossa história política recente, vimos os opositores iniciais do programa, diante da evidência de sua popularidade, aceitando-o e se esforçando para fazer crer que ele nada mais era do que uma cópia de uma iniciativa do seu próprio grupo. E, importante para meu argumento, mais uma vez acionando o repertório da "lição de casa". Bem se vê que nessa narrativa o nosso baixo clero pode até acertar mas, quando o faz, é porque seguiu a inspiração que vem do 
topo da hierarquia cultural. Mas além do espaço estritamente intelectual da sociedade, será que essas "preciosidades" sobre autoria e plágio podem se tornar relevantes no debate político ${ }^{9}$ e alterar as preferências eleitorais? Ao que tudo indica acontece o contrário, consagrando a novidade que, "certo ou errado", a memória popular associa aos governos petistas.

\section{A fratura consolidada}

As diversas fissuras da doxa e da hegemonia cultural das elites tradicionais medidas pelas escalas correntes foram finalmente consagradas em dois tópicos bastante diretos. E de maneira eloquente para corroborar nossa cronologia, ambos no imediato início do segundo mandato de Lula, logo após o terremoto do "mensalão". O primeiro deles na planificação dos programas de saneamento básico, em que a questão social foi invocada diretamente para criticar o processo de privatização dos serviços públicos. O argumento foi de que um serviço público muito importante para milhões de cidadãos não poderia ficar nas mãos da iniciativa privada, porque a lógica que deveria guiar seu funcionamento era a de atender ao público e não ao capital (Chico de Gois 06/01/2007). ${ }^{10}$ Assistimos assim, de maneira clara e cristalina, ao "rejunte" de uma associação que tinha sido desjuntada pela doxa dominante.

O grande teste, entretanto, parece ter sido na avaliação da contabilidade do sistema previdenciário nacional. Esta questão era uma das mais intensamente abordadas pelos economistas ortodoxos e os jornalistas de destaque na grande imprensa, que criticavam o que julgavam ser o descalabro da Previdência e vaticinavam sua falência, avançando números que provariam esses diagnósticos. E eis que a contabilidade que sustentava o futuro desastre foi "desautorizada" por Lula e Dilma (Leitão 30/01/2007). ${ }^{11}$ Surpreendentemente, o mundo não acabou: nem antes, uma vez que a ridicularização desses agentes que ousaram desafiar a verdade estabelecida não se produziu; e nem depois, já que a incidência do tema na mídia decresceu sem que o desastre anunciado se concretizasse. E, alguns dias depois da primeira ousadia, observamos o outro desafio à ortodoxia, dessa vez através da crítica direta ao processo de privatização, tido até pouco tempo atrás como um "benfeito pacificado" da história econômica e administrativa do Brasil.

Como tais atos foram possíveis? A resposta a eles mostra mais uma vez a pertinência da nossa história cultural escrita a partir da ideia de baixo clero. No auge das eleições de 2006, a candidatura de Geraldo Alckmin (representante do PSDB - Partido da Socialdemocracia Brasileira - partido de 
Cardoso e então ex-governador do estado de São Paulo) acusava os petistas de terem criado uma "central de boatos" para denegrir seu programa e reputação. Através de golpes culturais baixos, os petistas estariam tentando indispor o candidato com o seu eleitorado (O Globo 06/10/2006). Na linguagem do debate eleitoral daquele momento: "Em Pernambuco, Alckmin disse que o governo Lula criou a 'mentirobrás' — referência a uma 'central de boatos' responsável pelos rumores de que o PSDB pretende privatizar estatais e fazer cortes no Bolsa Família. O tucano anunciou a formação de um grupo de parlamentares para combater os boatos. 'Vamos criar esse grupo para desmentir essas coisas, dizer a verdade ao povo brasileiro e colocar os pingos nos is'" (Scolese 13/10/2006). Evidentemente que na nossa chave analítica arbitrar esta acusação não tem muito interesse e nem mesmo é uma operação intelectual possível ou desejada. Antes, trata-se de constatar que mais uma vez estávamos diante de uma típica acusação do alto contra o baixo clero e de avaliar a sua eficiência nos embates que se travavam, bem como o seu papel de revelador da relação de forças cultural imperante na nossa "república das letras (agora consideravelmente alargada)".

Em condições normais de temperatura e pressão, os esforços intelectuais do baixo clero são ignorados passiva ou ativamente. Passivamente quando os membros do alto clero sequer ficam sabendo das tentativas de subversão ou quando não se sentem atingidos por elas. Ativamente quando o ataque tem repercussão, mas os atingidos tentam manter o controle expressivo para "não passar recibo" de que os menores têm poder de fogo para feri-los. A ignorância ativa é uma estratégia importante e difícil. A defesa pública contra a crítica equivale a reconhecê-la publicamente e, implicitamente, a estabelecer uma equivalência com os acusadores. Para o pesquisador, a sua constatação sociológica se faz por indícios indiretos e não é evidente, sempre havendo espaço para controvérsia. Mas o mais interessante daqueles episódios é que, longe de ignorar as acusações de um jeito ou do outro, assistimos ao grupo peessedebista imputar àquela transgressão dos limites "legítimos" do debate político as razões para a sua derrota eleitoral. Em analogia com a França dos últimos Luíses que erigiu em política de Estado a caça implacável aos libelos e aos seus produtores, nosso alto clero "entregou o ouro": estava decididamente na defensiva e o mundo parecia fugir-lhe das mãos.

Depois daquelas eleições vimos uma enxurrada de boas notícias internacionais elogiando o presidente Lula e sua condução da economia, e nada poderia ser mais indicativo dessa tendência do que a manchete de The Economist, considerada a principal revista econômica em nível internacional: "Brazil takes off: Now the risk for Latin America's big success story is hubris" (Editor 12/11/2009). Justas ou fruto da miopia da mídia e da aca- 
demia internacional, pouco nos importa intrinsecamente. Dois pontos são mais importantes. O primeiro é a constatação de que o grupo que ocupava o governo federal demonstrava uma força inesperada no eixo cultural, que se consubstanciou na imposição internacional da sua versão da realidade brasileira. E o decisivo é que tal apreciação enfraquecia a capacidade de censura da ortodoxia nacional e sua força na imposição da doxa. E foi nesse momento da guerra cultural que a crise financeira internacional chegou ao Brasil.

\section{A crise financeira e a confirmação da tendência}

As crises econômicas de grandes proporções trazem sempre seu mais conhecido efeito trágico sobre as camadas menos privilegiadas das sociedades atingidas. Mas elas são também conhecidas como momentos em que a doxa dominante na condução dos negócios econômicos e sociais da sociedade pode se enfraquecer, possibilitando mudanças que antes nem seriam imaginadas ou esbarrariam na já conhecida ridicularização produzida pela quebra do bom senso. Seguindo o fio de nossa argumentação, chama a atenção o desfecho das ações empreendidas na grande crise atual pela administração Obama nos EUA. Ela fornece o forte contraste que singulariza a situação brasileira, não só pelo desfecho até o momento em que escrevo, mas principalmente pelas cronologias.

A candidatura recém-eleita e ainda não empossada deixa claro que considera a crise como uma oportunidade para mudar a relação assimétrica em que o sistema financeiro daquele país faz passar sua visão de mundo e questões como as de todo o país (Zeleny 09/11/2008; Seib 21/11/2008). E esse conjunto diagnóstico \& tratamento da crise para os fins dessa análise eram semelhantes àqueles que vimos no Brasil. Mas os diversos entreveros, tanto na esfera econômica quanto na midiática e principalmente na política, acabam reduzindo de forma paulatina as pretensões governamentais até impor novamente como dominante o ponto de vista hegemônico nos mercados financeiros (Sorkin 15/12/2009).

Nesse processo fica claro que as opções de enfrentamento e mesmo de enquadramento da crise não são apenas a emanação do pensamento de um sujeito cognoscente. O projeto de ampliar e melhorar a regulamentação da atividade financeira pelo Estado através de novas agências de controle acabou sendo consideravelmente mitigado, e as tentativas do Executivo daquele país morreram no muro do Legislativo (Protess 14/07/2011; Litchblau 27/07/2010). Em resumo, o Estado era o principal problema para a atividade 
econômica e a crise não alterou esta percepção nem tampouco os programas de ação que dela decorrem. E nada mais oposto ao que assistimos no Brasil do final da década de 2000 e início da de 2010. Aqui, a percepção é do aumento do peso físico e cultural do Estado numa configuração em que, anteriormente, o Estado representava apenas um problema. Testemunhamos diversas tentativas de recuperação do espaço perdido pela ortodoxia, mas claramente as linhas de força do período pós-2005 são outras e menos favoráveis aos seus tenores.

\section{A reação ortodoxa}

Uma muito interessante tentativa de recuperação do terreno intelectual e político surgiu, e foi fartamente popularizada, na reaparição pública dos "economistas do real" no final de agosto de 2011. ${ }^{12} \mathrm{O}$ palco escolhido foi o Instituto Fernando Henrique Cardoso, organização sediada no centro da cidade de São Paulo, palco de seminários sobre política, dotado de alta visibilidade midiática, criado pelo antigo presidente da República logo após o final de seu segundo mandato, que reúne seus arquivos políticos e é financiado principalmente por empresários privados (http://www.ifhc.org.br/).

Nesse evento a pureza intelectual fundamentalista se apresentou em grande estilo, mostrando o que aqueles agentes consideram como as incoerências, as zonas e as ações menos recomendáveis da parte dos seus sucessores na tarefa de administrar a economia brasileira. Os leitores entrados na sociologia econômica contemporânea dificilmente deixariam de lembrar o texto de Hirsch (Hirsch et al. 1990), já clássico, a respeito da especialidade: "Mãos sujas versus Modelos limpos". Colocamo-nos novamente diante da sedução de modelos de funcionamento da economia elegantes e bem armados dedutivamente: o alto clero da cultura econômica em ação tanto no intrínseco da argumentação econômica quanto nas estratégias culturais, feitas políticas, de desvalorização do conhecimento e atuação tidos como menos legítimos (Neumann 26/08/11; Fernandes 26/08/2011; Freire 28/08/2011).

Mas o sedutor parece ter entrado no seu inferno astral. A repercussão foi pouca e ruim. E o mais sintomático foram as reações de intelectuais que abrilhantavam o evento, como Giannotti, figura central do nosso construto e presença assinalada em todas as notícias sobre aquele acontecimento: "Desde o último artigo que li de Gustavo Franco tive a impressão de que vocês descreem da impossibilidade de se prover o welfare state. Mas o que pretendem fazer com essa gente?". Já Sérgio Fausto, filho de Bóris Fausto, outra figura importante do alto clero fernandista e diretor do IFHC, 
"reportou o impasse político, que chamou de 'situação aflitiva', para levar à rua as propostas daquele debate: O movimento pelo Real aconteceu num momento de desarticulação do sistema político. Agora está tudo articulado" (Fernandes 26/08/2011).

No Brasil, o início da segunda década do século XXI não apresenta um bom clima para lembrar o arcano da disjunção entre economia e política social, remetendo a segunda a um subproduto do futuro almejado em que a primeira estaria funcionando adequadamente. Mais do que isso, nossos heróis do fundamentalismo insistiam diretamente na obsolescência da ideia de Estado do Bem-Estar social, postando-se no halo da resposta financista internacional à crise financeira, que pretende justamente aproveitar a desestruturação econômica para desfazer o que considera ser o excesso de proteção social aos cidadãos europeus e norte-americanos. Nas palavras de Malan: "Os que tinham a Europa como modelo vão precisar rever seus conceitos". E, não por acaso, nos antípodas do programa do governo federal que os substituiu. Além da preferência nacional medida pelas eleições e lembrada até pelos participantes do evento.

E, mais uma vez, sempre é bom lembrar a tentativa permanente de usar as legitimidades cruzadas na esfera intelectual, econômica e política. Ainda que Cardoso observasse na ocasião que aqueles economistas são "homens que trabalham" e que por isso não poderiam se dedicar indefinidamente a simples tertúlias intelectuais, na verdade nossos protagonistas não perderam a viagem e aproveitavam o evento para se apresentarem em oráculos do chamado "jurismo". Trata-se do neologismo que designa a tendência de economistas, jornalistas e acadêmicos ligados ao mercado financeiro de sempre evidenciarem e repercutirem com muita intensidade as razões pelas quais sua ciência e bom senso indicam o desastre para o país em função de qualquer veleidade "voluntarista" dos governos ou dos partidos políticos em baixarem os juros básicos da economia.

O argumento central dificilmente poderia ser separado de uma lição moral sobre a já famosa expressão de Nelson Rodrigues (1993:52, seleção e notas de Rui Castro) o "complexo de vira-latas" (por "complexo de vira-latas" entendo eu a inferioridade em que o brasileiro se coloca, voluntariamente, em face do resto do mundo) e exemplo da já tradicional retórica dos efeitos perversos das ações bem intencionadas (Hirschman 1991). Ele diz que as tentativas de diminuição das taxas de juros básicos que liberariam recursos para as políticas sociais, de infraestrutura ou de fomento a atividades não financeiras podem levar o país à ruína, destruindo a estabilidade econômica duramente conquistada. A Ordem vem em primeiro lugar. Progresso, só se sobrar algum recurso. 
Manifestações dessa natureza ocorrem especialmente em momentos que antecedem as reuniões do Copom (Comitê de Política Monetária do Banco Central) que decidem as taxas para os próximos períodos. ${ }^{13} \mathrm{Mas}$ eis que também esse vaticínio não surtiu efeito. Não só os juros baixaram como também o mundo não acabou depois disso. E ainda soubemos das discordâncias e das descrenças dos próprios cardeais, mesmo no interior da basílica que organizou o conclave que deveria reiterar a fé. "Histerese do habitus" diriam, no registro erudito, os adeptos de Bourdieu (1997). Já os fãs da MPB de Chico Buarque [\& Caetano Veloso] lembrariam a música em que "o tempo passou na janela e só Carolina não viu". A receita que seus autores estavam acostumados a seguir deixou de fazer efeito mas, ao que parece, ela já estava incorporada como habitus dos sacerdotes e teólogos da ortodoxia econômica. A receita continua sendo tentada e podemos adivinhar a quem e a que seria atribuída a não aceitação da encíclica.

Examinemos então os nomes de destaque das equipes econômicas do governo FHC, do qual podemos dizer que se constituiu no paraíso da vanguarda financeira, e aqueles que despontam no governo Dilma. No eixo em que propus a análise, é difícil deixar de notar a extrema polarização nas prosopografias dos dois grupos. Os "fernandistas", mais conhecidos na mídia especializada e na academia como "os economistas do real", têm um conjunto de propriedades sociais que nos permite caracterizá-los como membros das elites consolidadas tanto no aspecto origem social, quanto no eixo do capital cultural, e que rapidamente se projetam como membros da vanguarda financeira, caminho que já estava bem iniciado antes daquele período. Já na equipe de Dilma, salta aos olhos a condição de intelectuais e agentes políticos de origem social e capital cultural bem mais modestos, além da notável condição prévia comum de funcionários públicos de carreira. As duas tabelas a seguir ilustram o contraste:

Os indicadores "profissão do pai" e "escolarização pré-universitária" dão suporte à afirmação referente ao capital social. Notadamente, os primeiros vêm de famílias suficientemente ilustres para acharmos registros enobrecedores de suas linhagens na internet. O item "pós-graduação", além de reforçar o anterior, também permite a afirmação relativa ao capital cultural. Por fim, o registro da "profissão antes" ancora o registro sobre o capital econômico. Encontramos uma notável homogeneidade escolar nos membros da equipe de FHC que começa nos colégios de elite cariocas e desemboca nas universidades norte-americanas da Ivy League ou equivalentes, o grupo considerado internacionalmente como o mais seleto da nobreza intelectual e social. 
Tabela 1 - Equipe de Fernando Henrique (nomes de destaque presentes no evento)

\begin{tabular}{|c|c|c|c|c|c|c|c|}
\hline Governo FHC & $\begin{array}{l}\text { Pedro } \\
\text { Malan }\end{array}$ & $\begin{array}{l}\text { Persio } \\
\text { Arida }\end{array}$ & $\begin{array}{l}\text { Edmar } \\
\text { Bacha }\end{array}$ & $\begin{array}{c}\text { Lara } \\
\text { Resende }\end{array}$ & $\begin{array}{c}\text { Gustavo } \\
\text { Franco }\end{array}$ & $\begin{array}{l}\text { Arminio } \\
\text { Fraga }\end{array}$ & $\begin{array}{l}\text { Luiz Carlos } \\
\text { Mendonça } \\
\text { de Barros }\end{array}$ \\
\hline $\begin{array}{c}\text { Escola } \\
\text { pré-universidade }\end{array}$ & $\begin{array}{c}\text { Santo Inácio } \\
\text { RJ }\end{array}$ & $\begin{array}{l}\text { Aplicação } \\
\text { SP }\end{array}$ & $\begin{array}{l}\text { Sto. Antonio } \\
\text { S. João del Rey }\end{array}$ & $\begin{array}{l}\text { Portugal(?) } \\
\text { pai diplomata }\end{array}$ & $\begin{array}{c}\text { São Vicente } \\
\text { RJ }\end{array}$ & $\begin{array}{c}\text { Santo Inácio } \\
\text { RJ }\end{array}$ & $\begin{array}{c}\text { Santa Cruz } \\
\text { SP }\end{array}$ \\
\hline Universidade & $\begin{array}{c}\text { Engenharia } \\
\text { PUC-Rio }\end{array}$ & $\begin{array}{l}\text { Economia } \\
\text { USP }\end{array}$ & $\begin{array}{l}\text { Economia } \\
\text { UFMG }\end{array}$ & $\begin{array}{l}\text { Economia } \\
\text { PUC-Rio }\end{array}$ & $\begin{array}{l}\text { Economia } \\
\text { PUC-Rio }\end{array}$ & $\begin{array}{l}\text { Economia } \\
\text { PUC-Rio }\end{array}$ & $\begin{array}{l}\text { Poli } \\
\text { USP }\end{array}$ \\
\hline Pós-gradução & $\begin{array}{c}\text { Doutorado } \\
\text { Economia } \\
\text { Berkeley, USA }\end{array}$ & $\begin{array}{l}\text { Doutorado } \\
\text { Economia } \\
\text { MIT, USA }\end{array}$ & $\begin{array}{l}\text { Doutorado } \\
\text { Economia } \\
\text { Yale, USA }\end{array}$ & $\begin{array}{l}\text { Doutorado } \\
\text { Economia } \\
\text { MIT, USA }\end{array}$ & $\begin{array}{c}\text { Doutorado } \\
\text { Economia } \\
\text { Harvard, USA }\end{array}$ & $\begin{array}{c}\text { Doutorado } \\
\text { Economia } \\
\text { Princeton, USA }\end{array}$ & $\begin{array}{c}\text { Esp. } \\
\text { Economia } \\
\text { USP }\end{array}$ \\
\hline $\begin{array}{l}\text { Militância } \\
\text { anterior }\end{array}$ & & VAR-Palmares & & & & & $\mathrm{AP}$ \\
\hline Profissão do pai & General & $\begin{array}{l}\text { Comerciante } \\
\text { na rua } \\
25 \text { de março }\end{array}$ & $\begin{array}{c}\text { Comerciante } \\
\text { líder político } \\
\text { local/lados } \\
\text { paterno e } \\
\text { materno }\end{array}$ & $\begin{array}{l}\text { Escritor famoso } \\
\text { neto } \\
\text { governador } \\
\text { Minas Gerais }\end{array}$ & $\begin{array}{c}\text { Político, } \\
\text { financista, } \\
\text { getulista }\end{array}$ & $\begin{array}{c}\text { Médico } \\
\text { dermatologista } \\
\text { renomado }\end{array}$ & $\begin{array}{c}\text { Médico } \\
\text { cardiologista } \\
\text { renomado }\end{array}$ \\
\hline $\begin{array}{c}\text { Invoca } \\
\text { genealogia }\end{array}$ & $\begin{array}{c}\text { Invocada } \\
\text { na imprensa }\end{array}$ & Sim & Oblitera & Sim & Sim & Sim & \\
\hline Nascido em & RJ & $\mathrm{SP}$ & Lambari,MG & $\mathrm{RJ}(?)$ & $\mathrm{RJ}$ & RJ & SP \\
\hline $\begin{array}{c}\text { Ano de } \\
\text { nascimento }\end{array}$ & 1943 & 1952 & 1942 & 1951 & 1956 & 1957 & 1942 \\
\hline $\begin{array}{c}\text { Profissão } \\
\text { antes/depois }\end{array}$ & $\begin{array}{c}\text { IPEA/ } \\
\text { Comitê } \\
\text { Unibanco }\end{array}$ & $\begin{array}{l}\text { Sócio Banco } \\
\text { Opportunity } \\
\text { (Daniel Dantas) } \\
\text { Banco BTG }\end{array}$ & & & $\begin{array}{l}\text { Professor } \\
\text { Financista }\end{array}$ & $\begin{array}{c}\text { Financista } \\
\text { internacional } \\
\text { (Soros/Private } \\
\text { Equit Nacional) }\end{array}$ & Financista \\
\hline
\end{tabular}

Em completa oposição, os membros da equipe petista, quando encontramos menção à escolarização pré-universitária, têm a frequentação maciça em colégios estaduais não só geograficamente dispersos, indicando pouco enredamento e homogeneidade anteriores, como também num período da história escolar brasileira em que tais instituições estavam bastante desacreditadas. Isto sem falar nas quase inexistentes e, quando aparecem, menos enfáticas menções às famílias do grupo na internet. E é aqui relevante considerar que essa investigação foi feita já em meados do décimo ano seguido de administração federal liderada por presidente oriundo do Partido dos Trabalhadores, que deveria ter suscitado a investigação das origens familiares dos membros importantes do seu governo.

Outra peculiaridade que salta aos olhos é a profissão original dos membros da equipe de Dilma e dela própria, aqui catalogada por ter sido membro da equipe de Lula. São funcionários públicos de carreira, 
Tabela 2 - Equipe de Dilma Rousseff

\begin{tabular}{|c|c|c|c|c|c|c|c|}
\hline Governo PT & $\begin{array}{c}\text { Dilma } \\
\text { Rousseff }\end{array}$ & $\begin{array}{c}\text { Guido } \\
\text { Mantega }\end{array}$ & $\begin{array}{c}\text { Paulo } \\
\text { Bernardo }\end{array}$ & $\begin{array}{l}\text { Nelson } \\
\text { Barbosa }\end{array}$ & $\begin{array}{c}\text { Arno } \\
\text { Augustin }\end{array}$ & $\begin{array}{c}\text { Alexandre } \\
\text { Tombini }\end{array}$ & $\begin{array}{c}\text { Henrique } \\
\text { Meireles }\end{array}$ \\
\hline $\begin{array}{c}\text { Escola } \\
\text { pré-universidade }\end{array}$ & $\begin{array}{c}\text { Sion, BH + } \\
\text { Estadual } \\
\text { Central }\end{array}$ & $\begin{array}{l}\text { Costa Manso } \\
\text { Estadual, SP }\end{array}$ & $\begin{array}{c}\text { Pedro II } \\
\text { Estadual, SP }\end{array}$ & $\begin{array}{l}\text { Princesa } \\
\text { Isabel, RJ }\end{array}$ & & Estrangeiro & \\
\hline Universidade & $\begin{array}{l}\text { Economia, } \\
\text { UFMG; expulsa, } \\
\text { concluiu } \\
\text { UFRGS }\end{array}$ & $\begin{array}{l}\text { Economia } \\
\text { USP }\end{array}$ & $\begin{array}{c}\text { Geologia UnB } \\
\text { incompleto; } \\
\text { expulso ME }\end{array}$ & $\begin{array}{l}\text { Economia } \\
\text { UFRJ }\end{array}$ & $\begin{array}{l}\text { Economia } \\
\text { PUC-Rio }\end{array}$ & $\begin{array}{c}\text { Economia } \\
\text { UnB }\end{array}$ & $\begin{array}{l}\text { Poli } \\
\text { USP }\end{array}$ \\
\hline Pós-gradução & $\begin{array}{l}\text { Unicamp } \\
\text { incompleto }\end{array}$ & $\begin{array}{c}\text { Doutorado } \\
\text { Sociologia } \\
\text { USP }\end{array}$ & & $\begin{array}{c}\text { Doutorado } \\
\text { Economia } \\
\text { New School, USA }\end{array}$ & $\begin{array}{c}\text { Mestrado } \\
\text { incompleto } \\
\text { PUC-RS }\end{array}$ & $\begin{array}{l}\text { Doutorado } \\
\text { Illinois, USA }\end{array}$ & $\begin{array}{l}\text { Coppe UFRJ } \\
\text { Mestrado } \\
\text { Harvard } \\
\text { latu sensu }\end{array}$ \\
\hline \multicolumn{8}{|l|}{$\begin{array}{l}\text { Militância } \\
\text { anterior }\end{array}$} \\
\hline Profissão do pai & $\begin{array}{l}\text { Advogado e } \\
\text { comerciante } \\
\text { búlgaro }\end{array}$ & $\begin{array}{l}\text { Industrial } \\
\text { setor de móveis } \\
\text { fascista }\end{array}$ & $\begin{array}{c}\text { sem } \\
\text { indicação }\end{array}$ & $\begin{array}{c}\text { sem } \\
\text { indicação }\end{array}$ & $\begin{array}{l}\text { comerciante } \\
\text { veículos } \\
\text { usados }\end{array}$ & $\begin{array}{c}\text { Economista (?) } \\
\text { funcionário } \\
\text { organismo } \\
\text { internacional }\end{array}$ & $\begin{array}{l}\text { Advogado, } \\
\text { político } \\
\text { interventor GO } \\
\text { governoGetulio }\end{array}$ \\
\hline $\begin{array}{c}\text { Invoca } \\
\text { genealogia }\end{array}$ & & $\begin{array}{l}\text { Negativa. } \\
\text { Pai o queria } \\
\text { nos negócios } \\
\text { "Lukács de Löwy" }\end{array}$ & & & $\begin{array}{c}\text { Cid. honorário } \\
\text { Carazinho } \\
\text { antes carreira } \\
\text { do filho }\end{array}$ & & \\
\hline Nascido em & $\mathrm{BH}$ & Gênova, Itália & SP & RJ & $\begin{array}{l}\text { Carazinho } \\
\text { (RS) }\end{array}$ & Porto Alegre & $\begin{array}{l}\text { Anápolis } \\
\text { (GO) }\end{array}$ \\
\hline $\begin{array}{c}\text { Ano de } \\
\text { nascimento }\end{array}$ & 1947 & 1949 & 1952 & 1970 & 1963 & 1963 & 1945 \\
\hline $\begin{array}{c}\text { Profissão } \\
\text { antes/depois }\end{array}$ & $\begin{array}{l}\text { Funcionária } \\
\text { Assembleia } \\
\text { Legislativa, RS }\end{array}$ & $\begin{array}{l}\text { Professor } \\
\text { PUC-SP }\end{array}$ & $\begin{array}{c}\text { Funcionário } \\
\text { de carreira } \\
\text { BB }\end{array}$ & $\begin{array}{c}\text { Funcionário } \\
\text { de carreira } \\
\text { BCB }\end{array}$ & $\begin{array}{c}\text { Auditor } \\
\text { TCE / RS }\end{array}$ & $\begin{array}{c}\text { Funcionário } \\
\text { de carreira } \\
\text { BCB }\end{array}$ & Financista \\
\hline
\end{tabular}

nitidamente inferiorizados em todos os aspectos que costumam "facilitar a vida", aplainar as trajetórias sociais rumo ao espaço das elites da nação e do mundo. Neste ponto é difícil deixar de invocar a questão levantada por Bourdieu (2012) a respeito do papel dos intelectuais dominados na construção dos Estados nacionais, os atores que ele chama de grammariens (:548), retomando a problemática desenvolvida por Weber (1995) a propósito dos tipos de intelectuais "proletaroides". E a extensa bibliografia sobre o papel desses agentes em revoluções e transformações sociais importantes do passado desperta nossa curiosidade para procurar as variantes do fenômeno no Brasil contemporâneo.

A inferioridade em todos os eixos, em princípio, inabilitaria a equipe de Dilma a conseguir, com sucesso, qualquer inflexão de sentido, em especial aquelas contrárias à doxa. Muito menos a extrema ousadia de reenquadrar 
o papel do Estado como solução que, como vimos à exaustão, é sempre considerado pela doxa como um problema, senão o maior problema das sociedades contemporâneas. A eterna e delicada relação entre independência e autonomia do Banco Central é um ponto específico da questão do Estado que chama a atenção. Entrevistada, ${ }^{14}$ Dilma defende de maneira oblíqua sua opção por nomear uma diretoria daquele órgão totalmente formada por funcionários, mas não aceita a obviedade do bom senso financeiro standard enunciado pela jornalista, bem como diversas "ousadias" menos convencionais aos olhos dos "mercados" (Safatle 17/03/2011).

Da mesma forma, Delfim Neto, identificado como o principal autor de um período anterior de "desenvolvimentismo" e que não por acaso é um dos defensores mais frequentes das políticas petistas ditas "neodesenvolvimentistas" diante da ortodoxia, relata posições e situações mutatis mutandis análogas no início de sua atuação como ministro dos regimes militares (Safatle 10/02/2012). Se, de um lado, a situação política em que ele e seu grupo se moviam era completamente diversa, por outro, a analogia de posicionamento sociológico dele e de sua equipe não poderia ser maior que a do nosso "baixo clero petista". De início, a estranheza das elites tradicionais quando assumiu pela primeira vez o Ministério da Fazenda em 1967: “No Rio [sede do Ministério da Fazenda naquele período], era o seguinte: chegou esse gordo, italiano e vesgo. Nós vamos matá-lo em seis meses, tá certo? E, além de tudo, tem uns animais estranhos com ele, uns japoneses" [A reportagem indica os nomes de: Affonso Celso Pastore, Paulo Yokota, Milton Dallari, Eduardo de Carvalho, Flávio Pécora, Carlos Antônio Rocca, Carlos Viacava, Carlos Alberto Andrade Pinto, Nelson Mortada, Akihiro Ikeda e Gustavo Silveira]. Ele quem?

aquele paulista caipira [que] não aguentaria até o fim do ano, [...] filho de Dona Maria Delfim, que costurava para fora e de José Delfim, [que] trabalhava na CMTC, empresa de transportes da prefeitura de São Paulo e que fez o curso primário num grupo escolar e contabilidade na Escola Técnica Carlos de Carvalho, [cujo] sonho era engenharia, mas o dinheiro da família era curto para um curso puxado, que não lhe permitiria trabalhar meio período.

E, depois, a questão do Banco Central. Referindo-se ao final de uma primeira experiência de autonomia em 1966, diz que

O Brasil estava numa recessão brutal nessa época. [...] Para flexibilizar as políticas fiscal e monetária, porém, era preciso acabar com o curto período de independência do Banco Central, criado em 1964, e demitir o primeiro presidente da instituição, Dênio Nogueira. [Segundo Delfim], "Não acaba a autonomia. 
O que acaba é a independência, que era um negócio absurdo". [Roberto] Campos ficou irritado com a exoneração de Dênio.

No seu estilo habitualmente cáustico, recoloca historicamente o argumento daqueles que julgam que a "independência" do Banco Central é uma usurpação dos direitos democráticos da cidadania por parte de uma elite cultural de economistas, que pretenderia ser portadora de uma racionalidade atemporal que iria além das preferências populares - uma bela metáfora para designar o nosso "alto clero": "Campos era uma figura inteligente, brilhante e briguenta. Mas o que ele queria, na verdade, era continuar mandando no Banco Central independente". E o presidente Costa e Silva, que terminou com o experimento da independência, dizia: "O Banco Central é independente de quem? É de mim, mas não do Campos, né?".

\section{O "PiG" é uma crença típica da democracia política?}

No cenário contemporâneo é diferente. Quando a democracia política está bem estabelecida, a liberdade de imprensa e das elites culturais que dela se servem é norma inabalável e o seu uso, inevitavelmente assimétrico por aqueles grupos, alimenta a crença no nosso "PiG". Uma consequência é que qualquer veleidade antidoxa, especialmente aquelas identificadas com o "neodesenvolvimentismo", seria impugnada, primeiro, pelos intermediários culturais da sociedade e, em seguida, pelos próprios agentes governamentais encarregados de executar a "abominação" já que, em tempos dóxicos, estes últimos estariam submetidos à hegemonia das elites estabelecidas.

Em linguagem cotidiana, os bancários do Estado e os demais agentes governamentais fariam "corpo mole" num processo em cuja tipicidade os inovadores frustrados procurariam uma explicação conspiratória, e os intermediários tradicionais aplaudiriam o bom-senso dos funcionários, fechando o círculo e desarmando os agentes governamentais imbuídos de veleidades mudancistas. Mas a agudeza dos conflitos cultural e político, principalmente na segunda metade do primeiro governo Lula, empurraram os membros de seu governo para uma confrontação com a cultura econômica e política das elites que seria impensável em condições normais, sem a ocorrência dos escândalos que tinham no horizonte o possível impedimento daquela presidência (Campanha 21/05/2012; Bergamo 22/08/2006; Castellani 28/06/2008; Alencar 30/10/2006; Grün 2008b).

Voltando à nossa estrutura social em mutação, vemos então uma relação entre o enfraquecimento da doxa e a composição e a recomposição das elites 
que circulam no campo do poder nacional. Morfologicamente, um resultado desses não poderia ser descartado já que, como vimos, a população dotada formalmente de atributos para a criação intelectual, medida pela frequentação de cursos superiores e a outorga de diplomas, tem crescido exponencialmente na sociedade brasileira. Diversos fenômenos culturais, sociais e políticos denotam esta saliência. Positivamente temos o reconhecimento oficial e público das tendências artísticas e musicais surgidas das periferias das grandes cidades, como o grafite e o hip-hop, ${ }^{15}$ indo até o papel desempenhado pela blogosfera nas eleições de 2006 (Grün 2008b). Questionando as novidades e os grupos emergentes da vida intelectual e política, vimos, por sua vez, o aparecimento de rubricas autorreveladoras, como a do "baixo clero" acadêmico e sua expressão na política: a "central de boatos petista" que teria agido nas eleições de 2006, conforme o enredo que descobrimos a partir do "PiG" e dos partidários do governo anterior.

Mais recentemente, a mesma família critica a expansão do sistema público universitário federal e a adoção de cotas sociais e raciais no ingresso das universidades, e começa a usar a expressão "blogueiros sujos" como sucessora da "central de boatos petista" precedente (Fraga 19/08/2010). Vemos assim em toda a grandeza a versão brasileira deste traço não tão incomum da história: o papel relevante desempenhado pelos intelectuais menos bem postos nas transformações sociais, seu corolário no agendamento da temática do "excesso de intelectuais" e o perigo que tal distúrbio produziria na boa ordem social. Em situações de muita polarização social e ideológica, conforme querem Chartier (1982), Darnton (1982), Bourdieu (1981), esses intelectuais se transformam em agentes políticos eficientes, sendo capazes de canalizar a energia social que normalmente se dispersaria para transformações bem além daquelas que o "bom senso" tradicional considera possível ou desejado. ${ }^{16} \mathrm{E}$ a persistência da temática do "baixo clero" mostra que não é por acaso que eles serão atacados sem dó pelas elites intelectuais e políticas tradicionais.

É interessante notar que o contencioso vai bem além da questão mais diretamente material das prebendas, comendas e encomendas que o reconhecimento intelectual pode propiciar na sociedade brasileira contemporânea. Um dos pontos mais evidentes é que nossos "economistas do Real" estão solidamente instalados nos pontos mais altos da pirâmide econômica e fornecem referências intelectuais e sociais para as elites tradicionais bem estabelecidas. E também poderíamos dizer com segurança que o destino foi bem mais generoso para Delfim do que o foi para seus vizinhos de infância no Cambuci ou seus colegas do curso de Contabilidade. Mas, apesar do sucesso inegável do grupo e do seu "oponente" (sugestão que se magnifica pela proximidade temporal das manifestações), seus posicionamentos 
públicos denotam a necessidade expressiva de se justificarem para a sociedade e, muito provavelmente, para eles mesmos. Estamos então diante de constrangimentos identitários que refletem as tensões no campo do poder do Brasil desse início do século XXI. Também eles são altamente indiciários para a sociologia que se ocupa do período que atravessamos.

Nas discussões sobre o "baixo clero", Bourdieu $(1988,1992)$ sugere que a força social desse agrupamento pode vir da homologia de posição do grupo no espaço cultural com a posição das classes subalternas na estrutura social como um todo, que levaria o grupo a produzir mensagens bem recebidas pela maioria quantitativa e subordinada da sociedade, mas que seriam correlativamente abominadas pelas elites tradicionais e os setores sociais sob sua influência direta. Neste caso, poderíamos explicar o sucesso eleitoral petista apesar do nosso "PiG". Mas como essa situação pode evoluir no tempo? A estranheza inicial dos petistas no campo do poder pode se ampliar diante dos seus oponentes diretos na esfera estética, intelectual ou política, mas há sinais, inclusive alguns idiossincráticos, que revelam o início de um convívio menos conflitivo com os grupos estabelecidos, em especial os agentes econômicos propriamente ditos. Ponto este que a presente análise, feita exclusivamente a partir das manifestações do nosso PiG e dos intelectuais tradicionais não deixa transparecer (Bergamo 12/08/2012).

Anotamos o inequívoco início meteco de Delfim, mas que sentido teria classificá-lo contemporaneamente de membro do "baixo clero"? Já Paulo Bernardo Silva, que no extremo oposto ao padrão "fernandista" ocupou diversos cargos importantes nos governos petistas e foi seu sucessor no Ministério do Planejamento no segundo governo Lula, dificilmente escaparia desta classificação. Mas mesmo aqui, o ex-estudante do Colégio Estadual Pedro II de São Paulo e aluno de graduação expulso da UnB - portanto muito inferiorizado no eixo do capital cultural certificado e eventualmente considerado "bancário", numa oposição simbólica a seus antecessores fernandistas, que são, inequivocamente, "banqueiros", e também "feio" ou "sem graça" — não parece ter encontrado dificuldades maiores de se legitimar no exercício dos vários cargos de $1^{\circ}$ escalão pelos quais passou nos últimos governos.

Construída a narrativa de que os petistas têm seu mandato derivado das aspirações populares que seriam sistematicamente ignoradas pelas elites tradicionais, que efetividade teria a supremacia cultural do nosso alto clero em indicar a "lição de casa"? Nesse modelo de ação, episódios como o da formatação conspiratória do "mensalão" são momentos-chave para reiterar e aprofundar a independência do nosso "baixo clero".

Quem tenta estabelecer a "lição de casa" faz parte do grupo daqueles que querem tirar o povo do governo. Nesse contexto, o apoio de Delfim e ou- 
tros, como Luiz Gonzaga Belluzzo, é um reforço considerável para os petistas diante da crítica tradicional e na delicada tarefa de infundir e manter as convicções pessoais de que eles estão no caminho certo num espaço hostil, que tendencialmente desvaloriza suas trajetórias e condutas. Mas é também um aríete a conferir legitimidade aos dois últimos na batalha intelectual, política e principalmente identitária de definir o bom futuro do Brasil e a teoria econômica mais relevante para isso. Nesse sentido, ressaltemos a insistência de Delfim em lembrar a seus colegas/concorrentes que os modelos econômicos deveriam "incorporar as urnas" (Netto 2002). Esta é uma metáfora robusta para identificar as preferências populares. Trata-se de uma ordem de preocupações sagrada na sociedade contemporânea e esta nuance indica limitações importantes do constructo intelectual dos seus concorrentes.

Mas, como vimos acima, mesmo segundo os cardeais do agrupamento político e ideológico que lhes deu guarida, a versão ortodoxa da economia professada pelo "alto clero" não daria conta dessa esfera legítima e que, por isso, dificilmente poderia ser retida pela "opinião popular" apesar da sua alteza intrínseca. ${ }^{17} \mathrm{Na}$ esfera da legitimação dos governos petistas, essa postura de desafio à ortodoxia é também interessante porque assume \& legitima a rejunção da esfera, considerada como estritamente econômica, com a da ordem social. E eis mais uma vez a homologia entre espaços diferentes explicando e reforçando um caminho da sociedade.

Bem se vê que as construções conspiratórias, tidas como idiossincráticas, existem e se reforçam num espaço social propício a elas. E aqui é impossível deixar de lembrar as lições de Marc Bloch sobre a propagação de rumores nas trincheiras da $1^{\text {a }}$ Guerra Mundial e sua sistematização sociológica contemporânea (Bloch et al. 1997; Aldrin 2005). A única propriedade sociologicamente relevante é a verossimilhança. Deixemos a "verdade" para os moralistas ou perguntemos aos filósofos sobre o significado analítico deste termo que encanta nossas relações cotidianas (Hacking 1983; Daston 2007). De um lado, a crença no nosso "PiG" e seu halo de iniquidades. Do outro, a insistência extemporânea na lição de casa como antídoto para essa "bobagem" (Bucci 13/08/2012). Impossível imaginar uma situação de "esclarecimento" dessa pendência. Pelo contrário, só podemos esperar o aguçamento da guerra cultural que se torna cada vez mais identitária. ${ }^{18} \mathrm{~A}$ advertência de Kraus/Adorno anotada acima não deixa dúvidas sobre os riscos dessas práticas de esgarçamento do tecido cultural. Mas nossa análise também traz indicações de que esse perigo ronda inevitavelmente a adoção das políticas econômicas, sociais e educacionais heterodoxas.

Podemos pensar em apaziguamentos a partir dos dois lados. De um deles, através da passagem de membros do "alto clero" para o apoio às 
políticas do baixo clero. O exemplo de Delfim, ainda que contextualizado, mostra bem essa possibilidade. Do outro, o assujeitamento do baixo clero, bem mais provável em circunstâncias normais. Diversos exemplos contemporâneos mostram políticas "de esquerda" ensejadas por grupos políticos saídos de formação que poderia ser catalogada como de baixo clero, sendo incorporadas juntamente com seus proponentes iniciais. São famosos os casos do New Labor inglês de Blair e das "alas esquerdas" (e piores alunos) da École Nationale d'Administration francesa, identificadas com o Partido Socialista daquele país.

Mas o exemplo brasileiro tem uma diferencialidade dificilmente escamoteável. Nosso baixo clero teve muito pouco contato prévio com o "alto". Não se trata, como no caso proverbial francês, do terço menos bem avaliado da mesma escola prestigiosa de origem. Trata-se de indivíduos e grupos cujo capital para a ocupação dos postos de responsabilidade é essencialmente de origem militante e não escolar. Para o bem ou para o mal, o contato social e a hegemonização que vêm juntos são menos automáticos, acontecendo mais em escalões inferiores. Não é por acaso que nos governos petistas crescem muito as denúncias do "PiG" sobre o "aparelhamento da máquina governamental por membros do partido". Uma burocracia governamental integralmente meritocrática segundo o padrão hegemônico seria mais permeável à argumentação dóxica e aceitaria melhor a imposição da "lição de casa". E até poderíamos dizer que a ilegitimidade do baixo clero transparece na incapacidade de dizer publicamente que o seu padrão de excelência não coincide com o da ortodoxia. No único caso repertoriado, assistimos a uma batalha feroz derivada da nossa guerra cultural e que segue em grandes linhas a mesma demarcação da polêmica sobre a independência do Banco Central na qual prevaleceu, pelo menos provisoriamente, o novo padrão de excelência intelectual e econômico, ainda que com um desfecho incerto (Patu 18/12/2008, 26/08/2012; Otta 19/12/2008; Carneiro 26/08/2012).

\section{O alto custo de usar o capital cultural na esfera política}

Outro ponto singular foi a particularidade do governo de Cardoso, capitaneado nada mais nada menos do que pelo "Príncipe dos Sociólogos" — denominação que na nossa guerra cultural não poderia ser mais propícia à identificação das suas manifestações como a voz mesma do alto clero (Fraga 05/08/2010). Na conhecida estrutura tripartite, em geral o poder intelectual é parcialmente independente do poder político e zela pela sua autonomia. Nosso "alto clero" é antes de tudo clero, e seria ponto essencial da sua 
identidade e legitimidade no próprio espaço intelectual a independência em relação ao poder temporal. Nas circunstâncias dos governos FHC houve uma rara coincidência entre estes dois poderes, criando uma concentração de legitimidade política, econômica e intelectual sem precedente e devotada a uma causa bem explicitada e não totalmente pacificada: diminuir o peso do Estado, em particular, através da privatização das antigas empresas públicas.

Este objetivo era comum não por acaso. Interessava às vanguardas financeiras que operacionalizaram e cresceram exponencialmente com a privatização. Também deveria destruir as corporações enquistadas na máquina pública, em especial nas empresas estatais, que seriam os principais pontos de apoio dos adversários petistas de Cardoso e seu grupo na sociedade, principalmente a partir da greve dos petroleiros no início do seu primeiro período. Tal acúmulo de poderes e a fixação do Santo Graal da privatização, que levaria o país a um deslanche de suas potencialidades adormecidas, produziu uma situação de extrema agudeza nas disputas da esfera cultural. Nela, a desqualificação dos "dinossauros" que se opunham ao desiderato, produzida e instigada diretamente pelo presidente da República, embora compreensível no quadro da disputa, equivalia a uma espécie de morte civil dos seus adversários, com direito a enterro no cemitério do Parque Jurássico, como enunciou na época Maria da Conceição Tavares (30/03/97).

\section{Conclusão: os usos problemáticos do capital sagrado numa arena profana}

Seria difícil imaginar quadro mais adverso ao "baixo clero" do que essa configuração montada e sistematicamente reiterada durante os governos Cardoso. Mas esse armamento pesado a favor da hegemonia ao mesmo tempo cultural e política de seu grupo engendrou uma armadilha. Ao conspurcar a esfera intelectual com a política e mesmo com a econômica, tal concentração deslegitimou a especificidade do poder intelectual de seu grupo, que passou a ser vista como simples emanação de seus interesses materiais e políticos. Um primeiro golpe contra a sua hegemonia pode ser anotado na incapacidade de caracterizar o "apagão elétrico" como um evento fortuito e não uma falha importante do seu governo, ${ }^{19}$ como acabou registrado apesar dos esforços concentrados do seu grupo, e provavelmente diminuiu as chances de Cardoso de eleger seu sucessor (Grün 2005a). Em seguida, podemos anotar a continuidade da deslegitimação com o nosso "mensalão", que tornou realidade o que seria apenas uma possibilidade. 
Olhando a configuração pela ótica da teoria do poder simbólico de Bourdieu, seria difícil não concluir que no período Cardoso o espaço cultural, totalmente comandado de cima e num processo de reforçamento mútuo com os poderes temporais, terminou funcionando mais como um aparelho do que como um campo. Essa situação gera segurança total para as elites no curto período em que o trunfo cultural é usado maciçamente, mas em que o trade-off enfraquece a alquimia social que produz duravelmente a sua legitimidade quando o campo funciona dentro das suas próprias regras. Numa linguagem mais cotidiana, poderíamos dizer que no governo Cardoso o grupo que se atribuiu a condição de alto clero e que foi acatado nessa pretensão pelos nossos "tribunais da opinião pública" acabou "queimando o seu cacife" no uso das altas magnitudes de capital cultural de que dispunha quando o instrumentou nas esferas política e econômica.

Outro ponto que a objetivação nos indica é a necessidade imperiosa de esvaziar os conceitos de alto e de baixo clero de qualquer substância que vá além dos seus usos nos embates sociais. É evidente que essa tarefa de objetivação é extremamente delicada e penosa, já que falamos do espaço no qual nós mesmos nos movemos e vivemos com intensidade e, ademais, o encantamento é operação necessária para a eficácia simbólica e social do conceito. Grosso modo, os agentes que foram classificados como baixo clero no embate e assim registrados na análise cresceram no período. O medo do castigo diminuiu, assim como a obediência automática à imposição da "lição de casa", ainda que não a tenham terminado.

Analiticamente se percebe que a incomensurabilidade entre o capital militante e o capital cultural reconhecido é condição necessária para nosso (ex?) baixo clero continuar o caminho a que assistimos nos últimos anos. Ela é retroalimentada pelo conflito cultural que assinalamos, e a experiência dos dois primeiros anos do governo Lula nos dá pistas para intuir que sem essa dinamização o baixo clero seria incapaz de destoar do figurino a ele atribuído na ordem tradicional.

Um cenário de estabilização possível é o capital militante se perenizar em capital simbólico. A belicosidade incessante das elites culturais e políticas tradicionais diminui as chances de isto acontecer quando tenta deslegitimar os "companheiros" em todas as oportunidades que lhes são abertas. Nosso "PiG" e aqueles que se expressam no seu halo estão longe de se tornarem irrelevantes. Pelo contrário, como mostram a literatura e a experiência internacional recente entreaberta, não estamos diante de uma jabuticaba. Antes, essa configuração é elemento estrutural dos arranjos políticos contemporâneos. ${ }^{20}$

O nosso "baixo clero" só é baixo se aceitarmos a hierarquização construída integralmente via eixo do capital cultural certificado. Pelo menos até 
meados de 2012, desafiá-la diretamente parecia estar além das possibilidades do grupo que acedeu ao poder federal no início do século XXI. Essa ilegitimidade de origem fez valer o seu peso, mas foi várias vezes ultrapassada no período a partir da flexão de outros capitais ou de apoios que, como vimos, não são tão inesperados.

Os resultados foram relevantes para a conformação do Brasil contemporâneo, variando de sinal, é claro, de acordo com as famílias políticas explícitas ou implícitas daqueles que julgam o nosso presente. Em alguns anos saberemos se as novidades vieram para ficar ou se foram apenas uma excentricidade brasileira. Os exemplos contemporâneos de exceção à ortodoxia econômica nos levam ou a nacionalismos exacerbados a partir de origens culturais e políticas muito particulares, como nas culturas milenares do Extremo Oriente, ou à transformação do capital militante em capital simbólico reconhecido em toda a sociedade, como nas socialdemocracias consolidadas da Escandinávia.

O último exemplo costuma seduzir mais a família política que conforma a nossa jabuticaba econômica e política, enquanto os exemplos do Extremo Oriente são case studies dos economistas que desafiam a ortodoxia de sua profissão. A vontade e o "benchmarking" não são irrelevantes, mas o jogo é bem mais complexo do que a simples simpatia.

O partido ideológico representado pelo nosso " $\mathrm{PiG}$ " e aqueles que dele se servem estão longe de se tornarem irrelevantes. A eventual volta ao poder central dos partidos políticos que comungam desses ideais poria o novo constructo à prova. $\mathrm{O}$ aguçamento do conflito cultural faz prever que essa volta seria um "Thermidor". Mas o mundo passou na janela e é muito difícil e penoso voltar atrás. A sociedade mudou nos últimos anos e o regresso aos velhos e bons tempos implicaria a necessidade de destruir as novas posições ou reocupá-las com outros agentes. A primeira solução redundaria numa violência provavelmente não só simbólica. Mas é bom explicitar as linhas de força da configuração que examinamos. Elas deixam claros tanto as potencialidades quanto os perigos que rondam o Brasil de 2012.

Recebido em 19 de setembro de 2012

Aprovado em 19 de agosto de 2013

Roberto Grün é professor do Departamento de Engenharia de Produção e pesquisador do Núcleo de Sociologia Econômica e das Finanças da Universidade Federal de São Carlos. E-mail: <rgrun@uol.com.br> 


\section{Notas}

${ }^{1}$ Este texto baseia-se em pesquisas financiadas pelo CNPq e pelo processo $\mathrm{n}^{\circ}$ 2012/22657-9 da Fundação de Amparo à Pesquisa do Estado de São Paulo (FAPESP). Agradeço às agências pelos auxílios prestados.

${ }^{2}$ Exposta em Timms (2005:231 e seg.). Análises da produção do artefato intelectual "antissemitismo" na França do final do século XIX por setores excluídos do espaço político central daquele país e época são análogas e complementares para os fins do presente artigo. Ver Sternhell (1997) e Noiriel (2009).

${ }^{3} \mathrm{O}$ "apagão" elétrico foi um racionamento do fornecimento de energia elétrica na malha centro-sul da rede de distribuição de energia ocorrido entre 2000-01. Segundo diversos críticos, inclusive alguns apoiadores do governo de Fernando Henrique Cardoso, tal problema poderia ter sido evitado se o planejamento estatal tivesse sido mais acurado, pois havia energia sobrando no braço sul da rede elétrica brasileira, mas não havia cabos de interligação para transmitir essa sobra para a malha sudeste, onde ela era necessária. Tento sustentar a importância intrínseca desse evento e como ele se inscreve na lógica mais geral do conflito político de fundo cultural que atravessa a sociedade brasileira a partir dos anos 1950 (Grün 2005a).

${ }^{4}$ A PEC 192 - Proposta de Emenda Constitucional no 192 - foi a primeira iniciativa legislativa de vulto do governo Lula, apresentada logo no início da legislatura de 2002, e visava regulamentar o capítulo da atividade financeira, até então carente de especificação na Constituição Federal de 1988. Ver Oliveira (19/02/2003).

${ }^{5} \mathrm{PiG}$ - Partido da imprensa Golpista é uma denominação proposta pelo deputado Fernando Ferro (PT-PE) para criticar a imprensa mainstream, considerada conservadora e inimiga do progresso social que estaria sendo trazido pelo governo federal petista. Ver na Wikipedia: http://pt.wikipedia.org/wiki/Partido_da_Imprensa_Golpista. Foi popularizado a partir do seu uso sistemático no blog "conversa afiada", de Paulo Henrique Amorim (http://www.conversaafiada.com.br/). Em "Entre o 'PiG' e o 'Mensalão': o que as mitologias políticas dizem das realidades contemporâneas" (Grün, no prelo), tento mostrar como tal entidade se transformou num ponto essencial da mitologia política produzida nas fricções culturais do Brasil contemporâneo.

${ }^{6}$ E não nos esqueçamos da severa advertência presente nas palavras de Adorno, comentando e tentando sintetizar os textos de Kraus sobre a perversão da linguagem no período pré-nazista, que chama à responsabilidade os intelectuais que ou se deixam levar pelo ar do tempo, ou simplesmente ignoram olimpicamente essas situações: "Os horrores da linguagem que configurava e cuja desproporção em relação aos reais é ressaltada de preferência por aqueles que querem ocultar os reais são excreções sociais, que aparecem originalmente nas palavras, antes de destruírem rispidamente a vida pretensamente normal da sociedade civil, em que amadureceram quase despercebidamente, longe da observação científica corrente" (Adorno 1966:163). Uma 
boa contextualização do espaço social e filosófico onde tal crítica emergiu, bem como sobre a influência de Kraus na filosofia que estava sendo desenvolvida no período, encontra-se em Janik e Toulmin (1973).

${ }^{7}$ E a partir dessa digressão, a tentativa de definir o que foi "exatamente" o mensalão se torna uma tarefa inglória.

${ }^{8}$ Tento dar inteligibilidade para essa transformação do espaço público brasileiro em Grün (2008b), argumentando que o momento político brasileiro naquela ocasião criou no país um sentido específico para a ideia internacional de "blogosphere", referido justamente aos embates políticos então vividos.

${ }^{9}$ E não é sem efeito o fato de que tais políticas públicas brasileiras façam parte de famílias já implantadas anteriormente em outros países, como o Revenu Mininum d'Insertion, o bem conhecido RMI, o que permitiria dizer que se trata de uma tecnologia social consolidada antes da sua aplicação no Brasil. Essa constatação deslocaria a avaliação do sucesso ou fracasso de tal política brasileira da esfera da concepção para a da sua aplicação efetiva no muito mais extenso circuito brasileiro da pobreza urbana e principalmente rural. Nessa versão, negar a autoria petista seria uma silogística muito complexa.

${ }^{10}$ Esta questão se inscreve num debate iniciado em 1976, quando da publicação da série de reportagens sobre as "mordomias do setor estatal" no jornal O Estado de São Paulo, em agosto daquele ano, e que deflagrou a versão brasileira de um conjunto de ideias sobre política, economia e sociedade posteriormente denominadas de "neoliberalismo" (Kotcho 01/08/1976). A manifestação de Lula, naquele momento, sobre a necessidade de manter o saneamento estatizado e sujeito a uma planificação submetida primeiramente a considerações de alcance social (ao invés da atratibilidade do emprendimento para um eventual investidor privado) representa uma inflexão na cronologia. Sua admissão no debate público revelou uma sensibilidade social distinta daquela dos momentos anteriores.

${ }^{11}$ É interessante transcrever a fala de Dilma Rousseff, então ministra da Casa Civil, presente na referência acima: "É computada como déficit previdenciário uma série de políticas públicas, como a assistência aos idosos e toda a política de aposentadoria rural" [...] "Muitas vezes se exige que a Previdência faça um esforço para solucionar algo que não depende dela. O que muda é a contabilidade pública dela" (Agência Brasil 30/01/2007). Intrinsecamente ela não tem nada de marcante, a não ser que desafiava a ortodoxia econômica dominante. Mais interessante, numa apreciação pacificada pela distância cronológica, é verificar a falta de crítica audível ao que antes teria sido considerado como uma grave afronta ao bom senso econômico e uma manifestação de aventureirismo econômico do governo federal, punível com um aumento das taxas de juros.

${ }^{12}$ Atas "oficiais" do evento recuperáveis no caminho abaixo: http://www.ifhc.org. br/index.php? module $=$ conteudo\&class $=$ debate\&event $=$ ver\&id_debate $=682$. 
${ }^{13}$ O COPOM é constituído pelos membros da Diretoria Colegiada do Banco Central do Brasil: o presidente, que tem o voto de qualidade; e os diretores de Administração, Assuntos Internacionais e de Gestão de Riscos Corporativos, Fiscalização, Organização do Sistema Financeiro e Controle de Operações do Crédito Rural, Política Econômica, Política Monetária, Regulação do Sistema Financeiro, e Relacionamento Institucional e Cidadania. Sua dimensão pública se acentua nos momentos anteriores e que se seguem às reuniões mensais que podem alterar a taxa básica de juros, que são perscrutadas pela imprensa e pelo mercado financeiro por causa do enorme interesse econômico e político que desperta a fixação dessa magnitude central para o mundo financeiro. Detalhes sobre seu histórico, funcionamento e atividades no caminho a seguir em: http://www.bcb.gov.br/?COPOM.

${ }^{14} \mathrm{O}$ trecho relevante para nossos propósitos do momento: Valor: Mas o BC, no seu governo, tem autonomia? Dilma: O Banco Central tem autonomia para fazer a política dele e está fazendo. Tenho tranquilidade de dizer que em nenhum momento eu tergiverso com inflação. E não acredito que o Banco Central o faça. Eu acredito num Banco Central extremamente profissional e autônomo. E esse Banco Central será profissional e autônomo. Não sei se não estão tentando diminuir a importância desse BC. Valor: Por quê? Dilma: Porque não tem gente do mercado na sua diretoria. Valor: Mas pode vir a ter? Dilma: Pode ter, sim. Falar que tem que ser assim ou assado é um besteirol. Desde que seja um nome bom, ele pode vir de onde vier (Em: http://www.valor.com.br/arquivo/877535/dilma-vai-adotar-regime-de-concessaopara-aeroportos\#ixzz2WUkqACng).

${ }^{15}$ E é bom aqui referir o "Melô dos vileiro", de Emicida (Faixa 4 do CD Doozicabraba e a Revolução Silenciosa, 2011): "Eles querem saber como faz pra chegar?... Eu digo é nóiz, eu digo é nóiz... Alto clero do asfalto, a nata amor", indicando o enorme percurso que a categorização já percorreu na sociedade brasileira.

${ }^{16}$ Mas ver também uma discussão crítica dessas digressões em Boltanski (2012), bem como um posicionamento divergente em Maler (2012).

${ }^{17}$ Evidentemente que a tarefa é mais simples de se efetivar na esfera nacional do que na internacional. O jogo que estamos assistindo está apenas começando e toda a doxa internacional referenda as posições nacionais dos seus locutores nacionais. No seu início, a crise financeira internacional parecia estar indicando a relativização do conhecimento econômico "dóxico". A crise "2.0" parece apontar mais para a restauração intelectual da ortodoxia e mesmo a abertura do espaço social dos países ocidentais para experimentos de regressão do cordão de proteção social que parecia um traço já pacificado das sociedades contemporâneas. E vimos que nossos "economistas do real" não nos deixam esquecer a tendência internacional e da transgressão, em sentido contrário do óbvio legitimado pela conduta dos países "mais importantes do mundo" que o governo brasileiro estaria tentando empreender no período. Só faltou falar, e é altamente esperado que o digam em algum momento, que a bolsa-família seria uma "jabuticaba" (tida na discussão pública como única fruta genuinamente brasileira e usada implicitamente para deslegitimar ousadias que se opõem à doxa internacional -a única coisa diferente do resto do mundo que o Brasil pode produzir é a jabuticaba). 
${ }^{18}$ Os momentos mais agudos da disputa fazem surgir dois polos com geometria circunstancialmente variada, mas com núcleos cada vez mais constantes. Por exemplo, no início de 2010 podemos ver a questão do " $\mathrm{PiG}$ " a partir de dois eventos claramente opostos \& relacionados. O primeiro deles na interface entre o governo federal atingido pelos escândalos e os diversos grupos que contestam a predominância da mídia privada tradicional. O segundo agrupando justamente a mídia mainstream e seus apoiadores. Naquele momento o contencioso poderia ser identificado através da contraposição entre a "1a Conferência Nacional de Comunicação" (http://www. confecom.gov.br/), convocada por setores do governo e apoiada por diversos setores que criticam a mídia tradicional, e o colóquio " $1^{\circ}$ Fórum Democracia \& Liberdade de Expressão", organizado pelo Instituto Millenium, fortemente apoiado pela associação dos proprietários de jornais (Em: http://portalimprensa.uol.com.br/ portal/agenda/ 2010/02/18/ imprensa33824.shtml).

${ }^{19} \mathrm{O}$ diagnóstico de falha enunciado inclusive por apoiadores de Cardoso contrariados, como José Goldemberg e Antonio Ermírio de Moraes, diz que a política de contingenciamento de gastos, empreendida por Cardoso e operacionalizada por Malan através de cortes lineares de gastos, teria impedido a construção de uma linha de transmissão entre os circuitos sul e sudeste do sistema elétrico brasileiro. Essa integração teria evitado o racionamento de energia, já que havia energia sobrando na malha sul e faltando na sudeste. Nas palavras ácidas de Delfim ocorreu uma: "cruel barbeiragem de programação do setor energético [que] devorou, nas mais conservadoras expectativas, $2 \%$ do PIB em 2001/2002 pela restrição física da oferta de energia elétrica. O custo da energia subiu definitivamente com as mais graves e duradouras consequências para a eficiência produtiva nacional" (05/08/2003).

${ }^{20}$ E não só contemporâneos, como mostram Charle (2004) para a França no período entre o final do século XIX e a II Guerra Mundial, e Lustosa (2000), para o início da imprensa brasileira.

\section{Referências bibliográficas}

ADORNO, T. W. 1996. "Textos escolhidos. Introdução à controvérsia sobre o positivismo na sociologia alemã". In: Coleção Os Pensadores. São Paulo: Nova Cultural.

AGÊNCIA BRASIL. 2007. "Previdência não deve mais contabilizar investimento social como déficit". Disponível em: http://agenciabrasil.ebc.com.br/noticia/ 2007-01-30/previdencia-nao-devemais-contabilizar-investimento-socialcomo-deficit. Acesso em: 30/01/2007. ALDRIN, Philippe. 2005. Sociologie politique des rumeurs. Paris: Presses Universitaires de France.

ALENCAR, Kennedy. 2006. "Durante crise, ministros sugeriram renúncia". Folha de São Paulo, 30/10/2006. 
BERGAMO, Mônica. 2012. "Mensalão tá na moda: clientes da Daslu e do JK Iguatemi contam como veem o julgamento do caso; alguns maridos se queixam de bullying contra a era Lula, quando ganharam dinheiro". Folha de São Paulo, 12/08/2012. . 2006. "Lula afirma a artistas que elite quis 'fazê-lo sangrar'". Folha de São Paulo, 22/08/2006.

BLOCH, Maurice L. B.; BLOCH, E. et al. 1997. Ecrits de guerre 1914-1918. Paris: A. Colin/Masson.

BOLTANSKI, Luc. 2012. Énigmes et complots; une enquête à propos d'enquêtes. Paris: Gallimard.

BOURDIEU, Pierre. 1977. "Sur le pouvoir symbolique". In: Annales. Économies, Sociétés, Civilisations, 32(3):405-411. - 1981. "Décrire et prescrire. Note sur les conditions de possibilité et les limites de l'efficacité politique". Actes de la Recherche en Sciences Sociales, 38:69-73.

- 1988. Homo academicus. Cambridge, UK: Polity Press.

- 1992. Les régles de l'art: genèse et structure du champ littéraire. Paris: Editions du Seuil.

- 1997. Méditations pascaliennes. Paris: Seuil.

2012. Sur l'Etat: cours au Collège de France 1989-1992. Paris: Raisons d'Agir $\&$ Seuil.

BOURDIEU, Pierre \& BOUVERESSE, Jacques. 2000. "L'actualité de Karl Kraus". Actes de la Recherche en Sciences Sociales, 131(131/132):119-126.

BOUVERESSE, Jacques. 2001. Schmock ou le triomphe du journalisme: la grande bataille de Karl Kraus. Paris: Seuil.

BUCCI, Eugenio. 2012. "O mensalão e a 'pressão da mídia'". Revista Época, 13/08/2012.

CAMPANHA, Bernardo M. F. D. 2012.

"Mensalão foi tentativa de golpe de oposição e imprensa, diz Lula". Folha de São Paulo, 21/05/2012.

CARNEIRO, Mariana. 2012. "Neri assumirá verba similar à de foguetes: ao ser confirmado como presidente do Ipea, economista terá orçamento que cresceu $30 \%$ nos últimos cinco anos; Dinheiro para pesquisas econômicas chegou a R\$ 305 mi em 2011, mas publicação tradicional não teve o mesmo ritmo". Folha de São Paulo, 26/08/2012.

CASTELLANI, Marisa. 2008. "Lula temeu impeachment no mensalão, diz Carvalho". Agência Estado, 28/06/2008.

CHAMPAGNE, Patrick. 1990. Faire l'opinion: le nouveau jeu politique. Paris: Editions de Minuit.

CHARLE, Christophe. 2004. Le siècle de la presse 1830-1939. Paris: Ed. du Seuil.

CHARTIER, Roger. 1982. "Espace social et imaginaire social: les intellectuels frustrés au XVIIe siècle". Annales. Économies, Sociétés, Civilisations, 372:389-400.

- 2000. Les origines culturelles de la Révolution Française. Paris: Seuil.

CHICO DE GOIS. "Lula sanciona lei do saneamento e abre caminho para investimentos: ao aprovar o marco regulatório do setor, presidente faz críticas à privatização". O Globo, Rio de Janeiro, 06/01/2007.

COLLINS, R. 2004. Interaction ritual chains. Princeton, N.J.: Princeton University Press.

COLETIVO. 2006. "Les guerres de Karl Kraus". Disponível em: http://atheles.org/agone/ revueagone/agone35et36/index.htm135et36. Acesso em: 12/12/2012.

DARNTON, Robert. 1982. The literary underground of the Old Regime. Cambridge, Mass.: Harvard University Press.

- 1983. Bohème littéraire et révolution: le monde des livres au XVIIIe siècle. Paris: Gallimard/ Seuil. 
2010. The devil in the holy water or the art of slander from Louis XIV to Napoleon. Philadelphia: University of Pennsylvania Press.

DASTON, Peter Lorraine G. 2007. Objectivity. New York and Cambridge, Mass.: Zone Books. Distributed by the MIT Press.

DOUGLAS, Mary \& STEVEN, Ney. 1998. Missing persons: a critique of the social sciences. Berkeley, New York: University of California Press/ Russell Sage Foundation.

EDITOR. 2009. "Brazil takes off: Now the risk for Latin America's big success story is hubris". The Economist, 12/11/2009.

FAGUER, Jean-Pierre. P. 1995. Khâgneux pour la vie. Une histoire des années soixante. Paris: Centre d'Etudes de l'Emploi.

FARGE, Arlette. 1992. Dire et mal dire l'opinion publique au XVIIIe siècle. Paris: Ed. du Seuil.

FERNANDES, Martia. C. 2011. "O futuro segundo os pais do Real". Valor ECOnômico, 26/08/2011.

FRAGA, Plínio. 2010. "Ao comentar O Príncipe, Fernando Henrique pede silêncio a Lula". Folha de São Paulo, 05/08/2010. . 2010. "Serra acusa governo de financiar 'blogs sujos' e perseguir jornalistas". Folha de São Paulo, 19/08/2010.

FREIRE, Vinícius Torres. 2011. “Um programa de oposição radical: para economistas tucanos, 'transição completa' do país depende de privatização ampla, geral e irrestrita". Folha de São Paulo, 28/08/2011.

GANGNEUX, G. 1959. "Le bas clergé sous l'Ancien Régime: l'exemple d'une cure aux XVIIe et XVIIIe siècles". Annales. Économies, Sociétés, Civilisations, 14(4):745-749.

GAXIE, Daniel. 1978. Le sens caché inégalités culturelles et ségrégation politique. Paris: Editions du Seuil.
GIANNOTTI, José Arthur. 1986. Universidade em ritmo de barbárie. São Paulo: Brasiliense.

GRÜN, Roberto. 2005a. "Apagão cognitivo: para uma sociologia da crise energética". Dados - Revista de Ciências Sociais, 484:891-928. . 2005b. "Convergência das elites e inovações financeiras: a governança corporativa no Brasil". Revista Brasileira de Ciências Sociais, 20:67-90. - 2008a. "Escândalos, marolas e finanças: para uma sociologia da transformação do ambiente econômico". Dados - Revista de Ciências Sociais, 51:313-352. . 2008b. "Guerra cultural e transformações sociais: as eleições presidenciais de 2006 e a 'blogosfera'". Sociedade e Estado, 23:621-666. . No prelo. "Entre o 'PiG' e o 'Mensalão': O que as mitologias políticas dizem das realidades contemporâneas". Revista Brasileira de Ciências Sociais.

GUZZO, José Roberto. 2009. “Danos Menores". Veja, 22/07/2009.

HACKING, Ian. 1983. Representing and intervening: introductory topics in the philosophy of natural science. Cambridge, Cambridgeshire/ New York: Cambridge University Press.

HIRSCH, Paul; MICHAELS, Stuart \& FRIEDMAN, Ray. 1990. "Clean models vs. dirty hands: why economics is different from sociology". In: Structures of capital: the social organization of the economy. New York: Cambridge University Press. pp. 39-56.

HIRSCHMAN, Albert. O. 1991. The rhetoric of reaction: perversity, futility, jeopardy. Cambridge, Mass.: Belknap Press.

IPEA. 2011. "Comunicado do Ipea $\mathrm{n}^{\circ} 110$ : ocupação no setor público brasileiro: tendências recentes e questões em aberto", out. 2011. 
JAMIESON, Kathleen H. \& CAPPELLA, Joseph N. 2008. Echo chamber: Rush Limbaugh and the conservative media establishment. Oxford/ New York: Oxford University Press.

JANIK, Allan \& TOULMIN, Stephen. 1973. Wittgenstein's Vienna. London: Weidenfeld and Nicolson.

KOTCHO, R. 01/08/1976. "Assim vivem os nossos superfuncionários. Estado de São Paulo, São Paulo.

LAKOFF, Georges. 1996. Moral politics: what conservatives know that liberals don't. Chicago: The University of Chicago Press.

LEITÃO, Thais. 2007. "Previdência não deve mais contabilizar investimento social como déficit". Agência Brasil, Brasília, 30/01/2007.

LITCHBLAU, Eric. 2010. "Army of ex-financial regulators set to lobby agencies". New York Times, 27/07/2010.

LUSTOSA, Isabel. 2000. Insultos impressos: a guerra dos jornalistas na Independência, 1821-1823. São Paulo: Companhia das Letras.

MALER, P. C. a. H. 2012. "Usages médiatiques d'une critique 'savante' de 'la théorie du complot'". Agone, 47:167-178.

MCCORMICK, Peter. 1996. Starmaking realism, anti-realism, and irrealism. Cambridge, Mass.: MIT Press.

MOSSE, George L. 1998. The crisis of German ideology: intellectual origins of the Third Reich. New York: H. Fertig.

NETO, João M. 2011. "O PT e os seus bons advogados". O Estado de São Paulo, 02/12/2011.

NETTO, Antonio Delfim. 2003. "Crescimento e imposto sobre energia: 'Apagão' fez país perder a vantagem da energia farta". Valor Econômico, 05/08/2003.

- 2002. O mercado e a urna. Rio de Janeiro: Topbooks.
NEUMANN, Denise. 2011. "Para equipe do Real, reduzir taxa de juro agora exige paciência". Valor Econômico, 26/08/2011.

NOIRIEL, Gérard. 2009. Immigration, antisémitisme et racisme en France XIXe-XXe siècle. Discours publics, humiliations privées. Paris: Hachette Litteratures.

OLIVEIRA, Raymundo. 2003. "Governo já tem proposta para mudar o 192". Valor Econômico, 19/02/2003.

OTTA, Lu Aiko. 2008. "Concurso do Ipea provoca polêmica: conteúdo ideológico de questões foi criticado por professores e também por pesquisadores do instituto". O Estado de São Paulo, 19/12/2008.

PATU, Gustavo. 2008. "Concurso do Ipea faz ataque a neoliberalismo e globalização". Folha de São Paulo, 18/12/2008. .2012. "Sob Pochmann, pauta política do governo foi seguida de perto". Folha de São Paulo, 26/08/2012.

PELLEPORT, A. G. L. D. \& DARNTON, Robert. 2010. Les bohémiens. Texte imprimé roman. Edition présentée et annotée par Robert Darnton. Paris: Mercure de France.

PROTESS, Ben. 2011. "Wall Street lobbyists aim to 'reform the Reform'". The New York Times, 14/07/2011.

RODRIGUES, Nelson. 1993. À sombra das chuteiras imortais: crônicas de futebol. Seleção e notas de Rui Castro. São Paulo: Companhia das Letras.

SAFATLE, Claudia. 2012. "O homem que se reinventou". Valor Econômico, 10/02/2012.

. 2011. "Dilma vai adotar regime de concessão para aeroportos". Valor Econômico, 17/03/2011.

SCHUDSON, Michael. 1989. "How culture works". Theory and Society, 182: 153-180. 
SCOLESE, Eduardo. 2006. "'Aquela gente só sabe vender', acusa Lula; é a 'mentirobrás', diz Alckmin: Tucano anuncia formação de grupo de parlamentares para responder a ataques da campanha adversária". Folha de São Paulo, 13/10/2006.

SEIB, Gerald F. 2008. "In crisis, opportunity for Obama". The Wall Street Journal, 21/11/2008.

SEM AUTOR. 2006. "Tucano denuncia central de boatos do PT: Alckmin diz que petistas, e até ministros, estariam espalhando rumores para desestabilizá-lo". O Globo, 06/10/2006.

SINGER, Suzana. 2011. "Lixo ou notícia?". Ombudsman, Folha de São Paulo, 18/12/2011.

SORKIN, Andrew Ross. 2009. "Putting Obama on hold, in a hint of who's boss". The New York Times, 15/12/2009.

STERNHELL, Zeev. 1997. La droite révolutionnaire, 1885-1914: les origines françaises du fascisme. Paris: Gallimard. STF. 2012. "STF julga constitucional política de cotas na UnB". Disponível em: http://www.stf.jus.br/portal/cms/verNoticiaDetalhe.asp?idConteudo $=206042$. Acesso em: 26/04/2012.

TAVARES, Maria da Conceição. 1997. "Globalitarismo e neobobismo". Folha de São Paulo, 30/03/1997.

TIMMS, Eduard. 2005. Karl Kraus, apocalyptic satirist: the post-war crisis and the rise of the Swastika. New Haven: Yale University Press.

WEBER, Max. 1995. Economie et société. Paris: Presses Pocket.

ZELENY, Jeff. 2008. "Obama weighs quick undoing of Bush policy". The New York Times, 09/11/2008. 


\section{Resumo}

O texto pretende mostrar como a terminologia usada nos diversos conflitos profissionais do Brasil contemporâneo revela uma nova estrutura de distribuição dos capitais simbólicos no país. Esta novidade se reflete nas condições de possibilidade de governos oriundos da esquerda no espectro político e que praticam políticas econômicas e sociais tidas como heterodoxas. Para tanto, acompanha alguns usos de expressões como "alto e baixo cleros" e "lição de casa" para mostrar os efeitos cruzados das nominações em que são utilizados e das reações a elas. Especialmente, lança mão de alguns marcadores culturais e eventos significativos dos dez anos que se seguiram à primeira vitória presidencial de Lula, e tenta explicá-los e extrair algumas consequências do seu transcorrer para a análise cultural do período.

Palavras-chave "Mensalão", "PiG", Conflito cultural, Sociologia política durkheimiana, Guerra cultural.

\section{Abstract}

This article will show how the terminology used in diverse professional conflicts in contemporary Brazil reveals a new structure for the distribution of symbolic capital in the country. This new structure is reflected in the conditions of possibility for governments that lean towards the left of the political spectrum to practice economic and social policies that are deemed 'heterodox'. To this end, the article focuses on the use of expressions such as "upper and lower clergy" and "homework" to show the cross-effects of these terms and reactions to them. More specifically, it makes use of certain cultural markers and significant events in the ten years that follow the first presidential victory of Lula, trying to explain them and to extract some of the consequences of their elapse for the cultural analysis of the period.

Key words "Mensalão", "PiG", Cultural Conflict, Durkheimian political sociology, Cultural warfare. 